Article

\title{
In-Situ Crystallization and Continuous Modification of Chromian Spinel in the "Sulfide-Poor Platinum-Group Metal Ores" of the Norilsk-1 Intrusion (Northern Siberia, Russia)
}

\author{
Ivan F. Chayka ${ }^{1,2, *}$, Liudmila M. Zhitova ${ }^{1,3}$, Tatiana N. Antsiferova ${ }^{4,5}$, Adam Abersteiner ${ }^{6,7}$, \\ Artem Ya. Shevko ${ }^{1}$, Andrey E. Izokh ${ }^{1,3}$, Nadezhda D. Tolstykh ${ }^{1,3}$, Marina P. Gora ${ }^{1}$, \\ Valery M. Chubarov ${ }^{7}$ and Vadim S. Kamenetsky ${ }^{2,6,7}$ (1) \\ 1 V. S. Sobolev Institute of Geology and Mineralogy, Siberian Branch of the Russian Academy of Sciences, \\ 630090 Novosibirsk, Russia; zhitova63@mail.ru (L.M.Z.); sp@igm.nsc.ru (A.Y.S.); izokh@igm.nsc.ru (A.E.I.); \\ tolst@igm.nsc.ru (N.D.T.); gora@igm.nsc.ru (M.P.G.) \\ 2 Institute of Experimental Mineralogy, Russian Academy of Sciences, 142432 Chernogolovka, Russia; \\ dima.kamenetsky@utas.edu.au \\ 3 Department of Geology and Geophysics, Novosibirsk State University, 630090 Novosibirsk, Russia \\ 4 Institute of Geology of Ore Deposits, Petrography, Mineralogy and Geochemistry RAS (IGEM RAS), \\ 119017 Moscow, Russia; antsifer@yandex.ru \\ 5 Fersman Mineralogical Museum of Russian Academy of Sciences, 115162 Moscow, Russia \\ 6 School of Natural Sciences, University of Tasmania, Hobart, Tasmania 7001, Australia; \\ adam.abersteiner@utas.edu.au \\ 7 Institute of Volcanology and Seismology, Far Eastern Branch of the Russian Academy of Sciences, \\ 683006 Petropavlovsk-Kamchatsky, Russia; zond@kscnet.ru \\ * Correspondence: ivanlab211@gmail.com; Tel.: +7-9-137-723-224
}

Received: 22 April 2020; Accepted: 28 May 2020; Published: 30 May 2020

Abstract: Layers rich in chromian spinel (Cr-spinel) occur in numerous differentiated and layered intrusions. These layers are often characterized by elevated and even economic concentrations of platinum-group-elements (PGEs), but only scarce sulfide mineralization. One particular type of such lithology occurs in the roof parts of the Norilsk-type differentiated intrusions (Russia) and is referred to as the "sulfide-poor PGE ores". We investigated rocks containing variable enrichments in Cr-spinel, sulfides, and platinum-group minerals (PGMs) from two sections of the upper zone of the Norilsk- 1 intrusion, with a focus on Cr-spinel. The rocks are dominated by two lithological types: (1) leucogabbro/troctolitic and (2) olivine-gabbro. Fine-grained (5-100 $\mu \mathrm{m})$ disperse disseminations with varying modal abundances of $\mathrm{Cr}$-spinel are characteristic for the rocks studied. Those abundances range from scarce mineralization through to very dense (up to $30 \mathrm{vol}$. \% Cr-spinel) cloud-like accumulations. However, compact-grained accumulations and cumulate-like textures, which are typical for chromitites of layered intrusions, are not characteristic for the studied rocks. Instead, the disseminations exhibit chain- and trail-like alignments of Cr-spinel grains, which cross the boundaries between enclosing silicates, and sub-circular arrangements. The study revealed millimeter-scaled patchy distribution of $\mathrm{Cr}$-spinel compositions within a given dissemination with Cr-spinel chemistry being strongly correlated with a kind of the enclosing silicate. (1) In unaltered rocks, plagioclase hosts more magnesian Cr-spinel (Mg\# 30-60), while $\mathrm{Cr}$-spinel in mafic minerals is less magnesian (Mg\# 18-35). (2) In altered rocks, more magnesian Cr-spinel is hosted by less altered silicates, while strongly altered silicates mainly host less magnesian $\mathrm{Cr}$-spinel. Systematics of trivalent cations exhibits divergent trends, even on a scale of a thin section, and depends on a kind of hosting lithology. Leucogabbro/troctolite lithologies contain $\mathrm{Cr}$-spinel with anomalously low $\mathrm{Fe}^{3+}$ and extremely high Ti contents, whereas $\mathrm{Cr}$-spinel from olivine-gabbro lithologies have moderate $\mathrm{Fe}^{3+}$ and moderately-high Ti contents. It is envisaged that crystallization of $\mathrm{Cr}$-spinel and their host 
rocks occurred from viscous mingled magmas, which had different compositions and redox state. Subsequent processes involved (1) high-temperature re-equilibration of $\mathrm{Cr}$-spinel with enclosing silicates and (2) post-magmatic alteration and partial recrystallization of $\mathrm{Cr}$-spinel. During these processes, $\mathrm{Cr}$-spinel was losing $\mathrm{Mg}$ and $\mathrm{Al}$ and gaining Fe and Ti. These chemical trends are generally coincident with those established for other intrusions worldwide, but the upper zone of the Norilsk-1 intrusion seems to possess an exceptional variety of $\mathrm{Cr}$-spinel compositions, not recorded elsewhere.

Keywords: Cr-spinel; chromite; layered intrusion; Norilsk-1

\section{Introduction}

Platinum-group element (PGE)-bearing reefs enriched in chromian spinel (Cr-spinel, chromite) are found in some layered igneous complexes (e.g., Bushveld, Stillwater) and are among the main global resources of PGE [1-5]. Despite numerous attempts to unravel their origin, the underlying genetic processes responsible for their outstanding chromium and PGE enrichment are still a remarkable challenge for petrologists and economic geologists. Significant and relevant questions include how high quantities of chromium and PGEs can concentrate in a small volume rock and which processes are responsible for the geochemical links between these elements in different geological settings and, in particular, in mafic-ultramafic intrusions.

Differentiated intrusions of the Norilsk region (Figure 1A) are renowned for bearing one of the world's largest reserves of PGE, which are hosted in massive and disseminated sulfide ores [6-10]. Importantly, in the upper endocontact zones, there are discontinuous layers that consist of gabbro-, troctolite-, and picrite-like rocks with numerous patches of multi-grained $\mathrm{Cr}$-spinel disseminations and extremely high PGE contents (up to $70 \mathrm{ppm}$ ) [11]. The presence of these layers in most intrusions of the Norilsk ore field, along with their potential for exploration vectoring, have been emphasized in several studies [12-14]. These Cr-spinel rich rocks are comparable with the reefs of Bushveld, Stillwater and some other layered intrusions. However, there are two principal differences between reefs typical for the layered intrusions and the studied formations of the Norilsk-type intrusions. First, chromitites in layered intrusions (Bushveld, Kemi, Monchegorsk, Stillwater and others) tend to occur in their lower parts, while in the Norilsk-type intrusions, Cr-spinel rich lithologies are spatially related to the roof parts [1,15-17]. Second, most of the chromitite seams in layered intrusions are essentially planar and relatively continuous structures, while those in Norilsk-type intrusions, although being referred to as "layers" or "horizons," are discontinuous and have complex boundaries.

Cr-spinel is widely used as a petrological tool that can provide important insights into the origin of chromitites [18-25]. Approaches, based on chromite chemistry and chromite-hosted inclusions, proved to be efficient for Bushveld, Stillwater, and Rhum complexes. A number of implications, outlined in those studies, appeared to depart from "traditional" orthomagmatic attitudes and showed that the genesis of chromitites is much more complicated than simple accumulation from mafic melts and may involve assimilation of the wall rocks, percolation of evolved melts through cumulates and even sub-solidus re-crystallization and compaction of Cr-spinel grains [19,26,27].

Our study provides a large dataset on the textural and compositional characteristics of $\mathrm{Cr}$-spinel in the PGE- and chromite-enriched, sulfide-poor rocks of the Norilsk-1 intrusion, which were sampled at two different locations (Figure 1B). We investigated variations of $\mathrm{Cr}$-spinel compositions in a variety of rocks and their dependence on enclosing silicates. Even though the studied rocks are most renowned for their PGM contents, detailed discussion of the platinum group mineralization is provided in Tolstykh et al. [28], while this study is focused only on Cr-spinel and its implications for the petrology of these rocks. The obtained textural and chemical data provides further insights into the origin of Cr-spinel mineralization and host silicate matrix. 

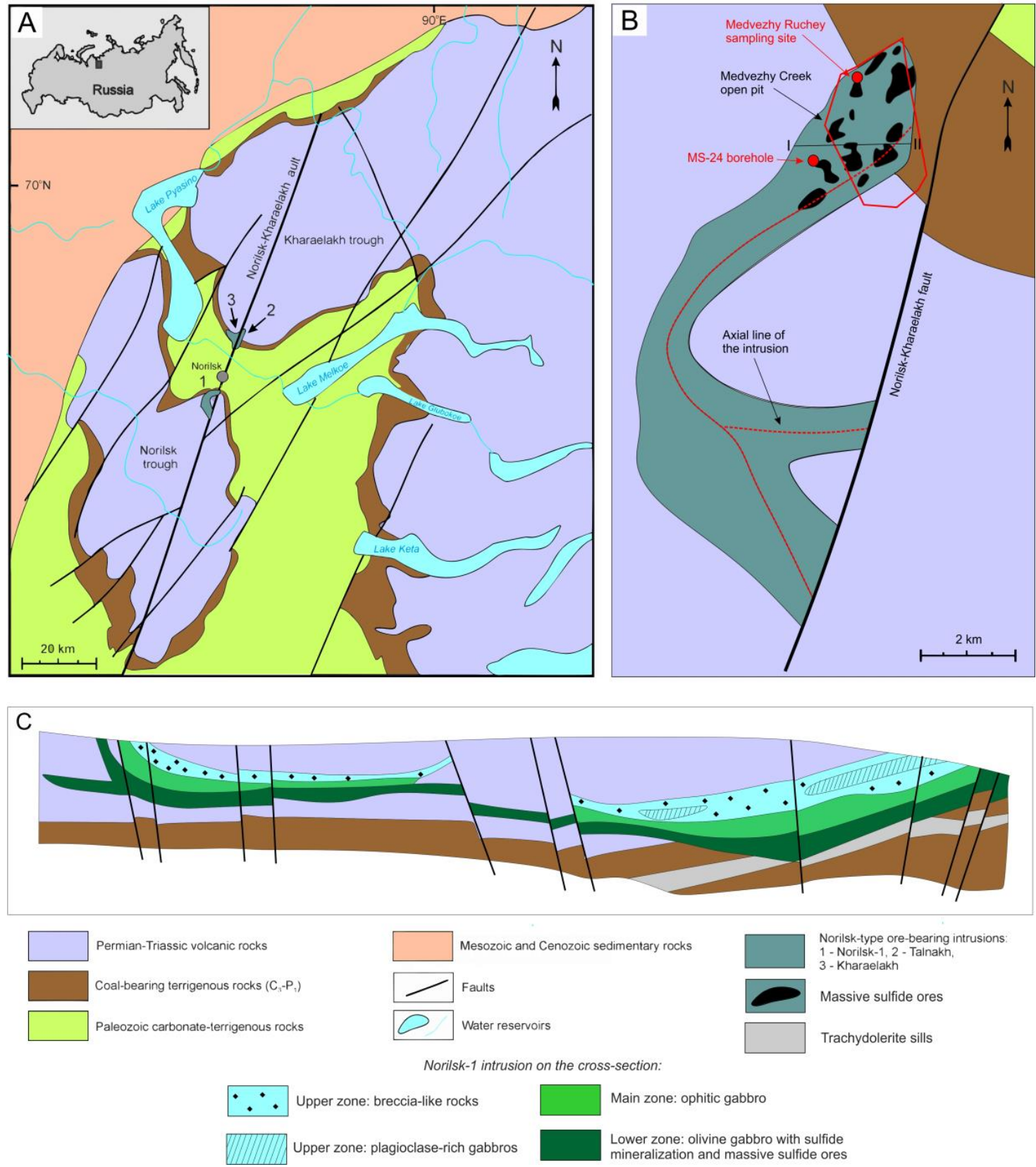

Figure 1. The Norilsk-1 intrusion and its surroundings. (A) Geological map of the Norilsk-Talnakh ore junction and the adjacent areas; (B) projection of the Norilsk-1 intrusion on the surface (outlined using borehole data). Modified after references [13,29]; (C) schematic cross section of the Norilsk-1 intrusion before extensive exploration of the Medvezhy Ruchey open pit [6,30].

\section{Geological Background}

The Norilsk-Talnakh ore province, which includes the Norilsk-1 intrusion, is located in Northern Siberia at the junction of the Siberian Platform with Tunguska syncline and Yenisei-Khatanga trough. Within this province, sill-like intrusions were emplaced into the upper part (from the Devonian to the Upper Permian) of the sedimentary cover of Siberian Craton and the earliest trap basalt suites [31,32]. The sedimentary sequence is composed of a variety of different rocks: fine-grained terrigenous rocks, coal-rich schists (e.g., black shales), evaporites, including massive anhydrite, and carbonate-bearing lithologies [8,31,33-37]. There are numerous intrusions in this region, and most of them contain $\mathrm{Cu}-\mathrm{Ni}$ sulfides, but only three intrusions (Talnakh, Khaeralakh, and Norilsk-1) are known to contain economic 
quantities of $\mathrm{Cu}, \mathrm{Ni}$, and PGE. Furthermore, these intrusions possess the highest concentrations of $\mathrm{Cr}$ and PGE in their roof parts compared with other differentiated intrusions in the area. The Kharaelakh and Talnakh intrusions are located in the southern part of the Kharaelakh Trough, whereas the Norilsk-1 intrusion is situated in the north-eastern part of the Norilsk Trough. The emplacement of these intrusions was controlled by the Norilsk-Kharaelakh fault (Figure 1A,B). According to previous studies, these intrusions are referred to as "Norilsk-type." They consist of at least three stratigraphic and lithological zones, which have sub-planar geometry and in most cases are well distinguished from each other (Figure 1C) [32,33]. The Lower Zone (LZ) is generally composed of ophitic gabbro, texturally variable gabbro with patchy textural patterns ("taxitic gabbro"), "explosive" breccia, leucogabbro, and different metasomatic rocks with massive sulfides at the endo-contact. The Main Zone (MZ) is represented by a stratified series of rocks, in which quite thick layers range upward from picritic ophitic gabbro and olivine-bearing gabbro to gabbro-diorite. The Upper Zone (UZ) is compositionally similar to the LZ in being dominantly composed of leucogabbro "taxitic" gabbro and pseudo-magmatic breccia. A characteristic feature of the UZ is the absence of sulfide-rich mineralization. However, discontinuous strata and lenses of rocks that are highly enriched in Cr-spinel and platinum-group minerals (PGM) with only subordinate sulfide ( $<1$ vol. \%) occur sporadically throughout this zone. Due to the scarcity of sulfide mineralization, these PGE- and Cr-rich ores were assigned the term "low-sulfide" in the Russian literature [13,32].

\section{Samples and Methods}

\subsection{Samples}

Samples of Cr-spinel-bearing rocks of the upper zone from two distant sections of the Norilsk-1 intrusion were examined. One set of the samples was collected in 2011 from the Medvezhy Ruchey (Bear Creek) mine (Figure 2A), which is operated by Norilsk Nickel LTD. The PGE-Cr-spinel enriched layer at this mine is represented by strongly inhomogeneous gabbro-, breccia-, and skarn-like rocks $[13,32,38]$, along with intermittent lenses of black shales, which are generally situated at the roof contact between the intrusion and Ivakinskaya suite basalts (Figure 2A-C). Although S.F. Sluzhenikin and the Geological Survey of Norilsk Nickel LTD performed extensive field studies of this horizon during the 1990s, by 2011, most of those outcrops were inaccessible for sampling or have been buried under cliff debris. However, we manage to undertake the sampling in the north-western side of the mine at the $300 \mathrm{~m}$ horizon (floor $274 \mathrm{~m}$, top $340 \mathrm{~m}, \mathrm{~N} 69^{\circ} 17^{\prime} 05,0^{\prime \prime}$ E 88 10'13,7') (Figure 2B). In the studied outcrop $(\sim 50 \times 20 \mathrm{~m})$, the PGE-Cr-spinel-bearing lithologies are represented by plagioclase-dominated rocks with different amounts of olivine, pyroxene, and Cr-spinel. On a smaller scale, the rocks appear to be of gabbro composition and largely ophitic texture with zones of abundant $\mathrm{Cr}$-spinel dissemination (Figure 2D). The PGE-Cr-spinel bearing rocks in the outcrop are overlain by a "transitional" layer, which although inaccessible, is most likely composed of leucocratic rocks with intermittent carbon-bearing pelites (black shales) and basalts, while the top of the outcrop seems to be composed mainly of metamorphosed basalts of Ivakinskaya suite (Figure 2B,C). Four samples were selected from the Cr-spinel-PGE-rich horizon in the studied outcrop (MR-14; MR-20; MR-30 and MR-31). 

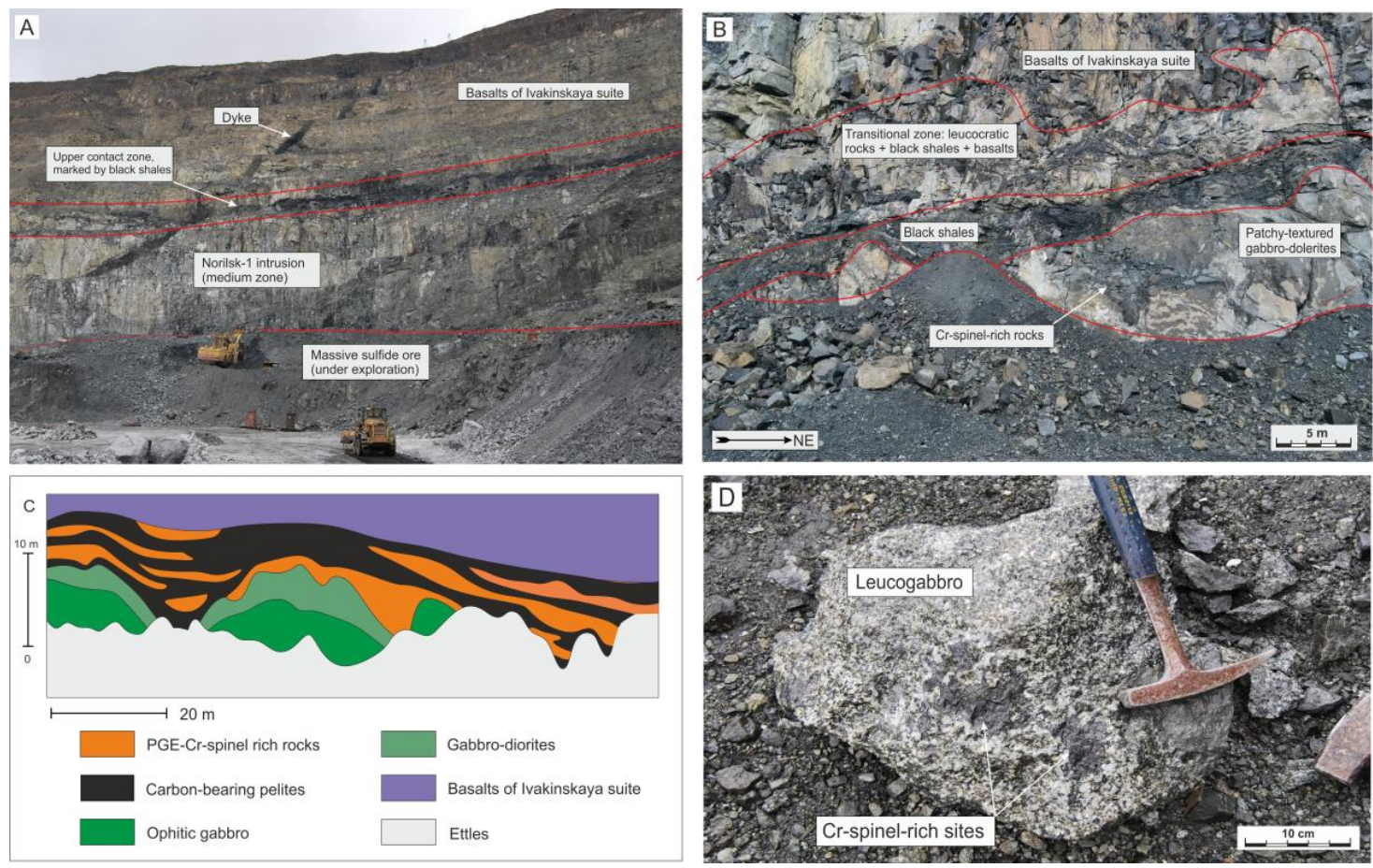

Figure 2. Field relationships of different rocks in the Medvezhy Ruchey open pit. (A) Layout of the open pit with outlined main geological bodies; (B) sampled outcrop on the $300 \mathrm{~m}$ horizon; (C) a geological sketch of the $270 \mathrm{~m}$ horizon (after [13]); (D) Leucogabbro with visible Cr-spinel-rich sites.

Borehole MS-24 was placed at the upstream of the Yuzhniy Ugolniy creek, currently buried under mine ettles $\left(69^{\circ} 16^{\prime} 25^{\prime \prime} \mathrm{N}, 88^{\circ} 8^{\prime} 1^{\prime \prime} \mathrm{E}\right.$ ) (Figure 1B). With the depth of $331 \mathrm{~m}$, it penetrated (top down) mine ettles (0-36.7 m), quaternary deposits (36.7-47.9), porphyric basalts and picrobasalts of the Gudchikhinskaya suite (47.9-158.0 m), tholeiitic and poikiloophitic basalts, tuffs and tuffites of Syverminskaya suite (158-269.1), basalts of Ivakinskaya suite (269.1-316.5 m), and the Upper zone on the Norilsk-1 intrusion (316.5-331 m) (Figure 3). The rocks of the intrusion are represented (top down) by breccia-like rocks with clasts of apobasaltic hornfelses, annealed coals and ophitic gabbro (316.5-322.0 m), patchy-textured (taxitic) gabbros with mingling of leucogabbro/troctolitic and olivine-gabbro lithologies (322.0-327.4 m), and ophitic gabbro of the Main zone (327.4-331.0 m) (Figure 3). Interval of the core between $321.9 \mathrm{~m}$ and $325.4 \mathrm{~m}$ contains numerous, yet uneven, Cr-spinel-rich domains and was sampled for the entire study. Samples from this borehole are labeled according to their meterage and are the following: MS24-321.9, MS24-322.3, MS24-323.4, MS24-324.0, MS24-324.3, and MS24-325.4 (Figure 3). Since their petrographic features are unique and thus essential for petrological constraints, we present their detailed description in the Results. 

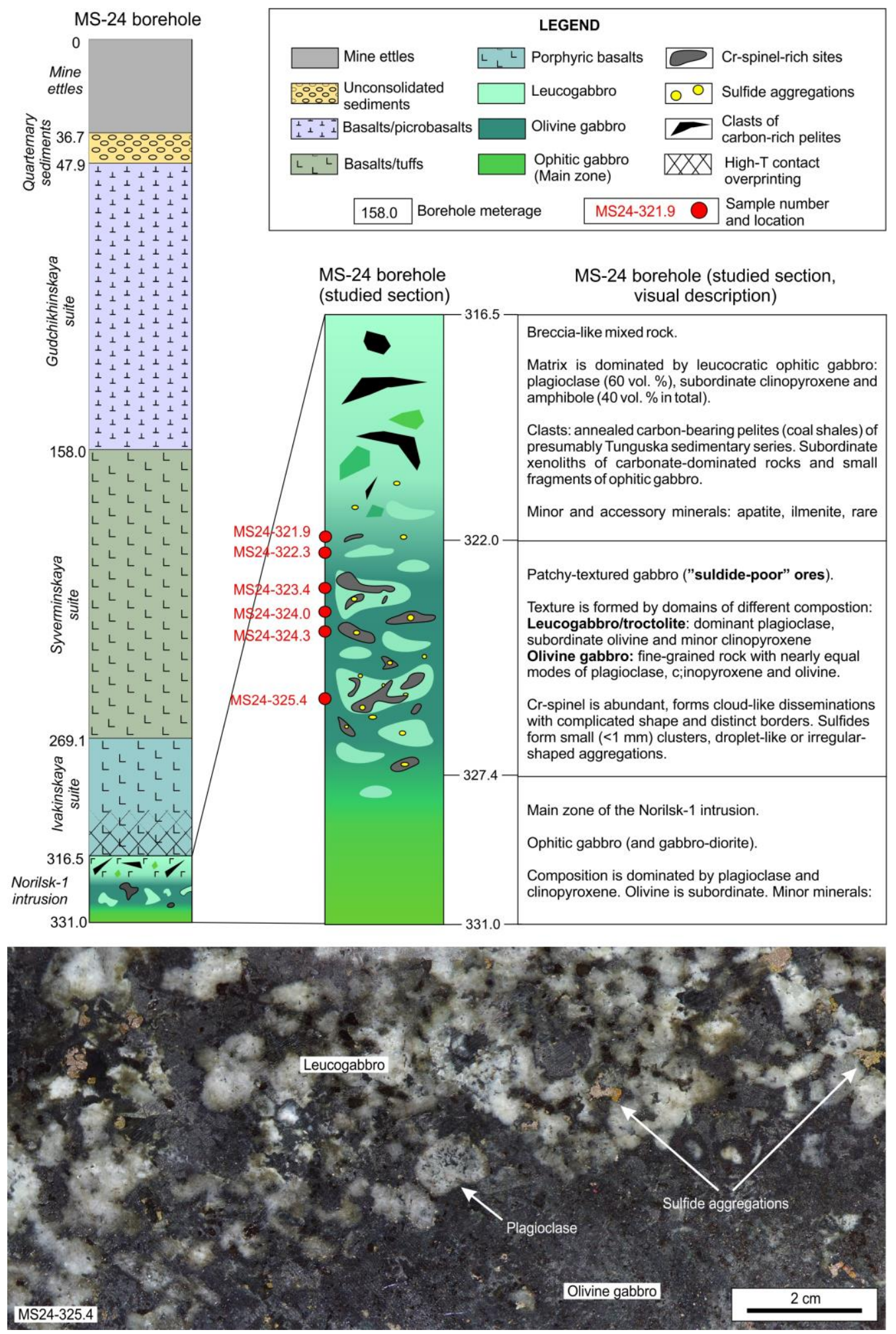

Figure 3. MS-24 borehole with a detailed description of the studied section and a photograph of a drill core from $325.4 \mathrm{~m}$ depth (sample MS24-325.4), representing textural heterogeneity of Cr-spinel-bearing rocks.

\subsection{Methods and Data Processing}

Polished thin sections $1 \times 0.5$ inch were prepared for petrographic and mineralogical studies. Grains of Cr-spinel were separated from crushed samples by gravitational concentration in water, 
with subsequent concentration in a heavy liquid (tribromomethane) and then mounted into epoxy mounts. Petrographic studies of the thin sections were performed on a Carl Zeiss Scope A1 microscope equipped with a Canon EOS 650D camera. Scanning electron microscopy (SEM) was employed for imaging of textures and mineral assemblages. Micro-analytical studies of the Cr-spinel grains and silicates were carried out employing both electron probe microanalysis with wavelength dispersive X-ray spectroscopy (EPMA-WDS) and scanning electron microscopy with energy dispersive X-ray spectroscopy (SEM-EDS). Compositions of sulfides and PGMs were determined using SEM-EDS.

EPMA was performed on JEOL JXA-8320 and JEOL JXA-8100 microprobes at the Analytical Centre for Multi-elemental and Isotope Research of the V.S. Sobolev Institute of Geology and Mineralogy (AC IGM SB RAS), Novosibirsk, Russia. All analyses were performed at $20 \mathrm{kV}$ and probe current $40 \mathrm{nA}$. Natural mineral compositions were used as standards during EPMA and were analyzed every 30-50 analyses. Imaging and quantitative analysis of mineral phases was carried out on Hitachi SU-70 Schottky field emission SEM fitted with Oxford INCA Energy XMax 80 silicon drift detector EDS system (University of Tasmania), Tescan Mira 3 LMU and JEOL JSM 6510 LV (IGM SB RAS, Novosibirsk), and Tescan Vega 3 (Institute of Volcanology and Seismology, Petropavlovsk-Kamchatsky). Probe current and acquisition time were selected individually on each instrument, while signal intensity during SEM-EDS examination was calibrated on artificial cobalt. Although applicability of SEM-EDS for quantitative analysis of minerals is debated, detailed investigations on several silicates and oxides (including Cr-spinel) have shown that this method allows to obtain numerical data on elements, which concentration is $0.3 \mathrm{wt}$. \% and higher [39]. Primary EDS data was converted to element concentrations using the Aztec software package, while the quality of EDS data was controlled by real-time monitoring of $\sigma$ value: element concentrations with $\sigma$ more than $0.3 \mathrm{wt}$. \% were considered to be inadequate. Subsequent comparison of data acquired by WDS and EDS methods substantiated the applicability of EDS for the purpose of this study, provided that all petrological implications are based on major elements in Cr-spinel, while elements with concentrations lower than $0.5 \%$ were not considered.

To evaluate $\mathrm{Fe}_{2} \mathrm{O}_{3}$ content, we calculated mole percentage of each element and used deficiency of trivalent $(\mathrm{Cr}, \mathrm{Al}, \mathrm{Ti}, \mathrm{V}$ ) cations with regard to divalent ones (Fe, $\mathrm{Mg}$ ). This method allowed to calculate $\mathrm{Fe}_{2} \mathrm{O}_{3}$ concentration, which was then was subtracted from total FeO to obtain a real content of FeO. Aside from routine data processing, we used graphical processing of back-scattered electron (hereinafter BSE) images, which allowed to visualize compositional features of Cr-spinel on a large area (up to a standard thin section) without employing specific equipment such as Micro-XRF technique. It was recognized that $\mathrm{Cr}$-spinel with different $\mathrm{Mg} / \mathrm{Fe}$ ratio has different brightness on grayscale BSE images. Comparison of microprobe data with BSE images of certain Cr-spinel grains revealed that this effect is explained by different atomic weights of $\mathrm{Mg}$ and $\mathrm{Fe}$, rendering $\mathrm{Mg}$-rich $\mathrm{Cr}$-spinel grains darker and Fe-rich ones brighter. Although it is not usually evident from simple (low-contrast) BSE images (Figure 4A), a range of Cr-spinel grayscale hues is still significant enough to resolve when the levels are adjusted in a raster processing software. We performed the processing in Adobe Photoshop CC, release 20.0.0. Using the "Adjustment $\rightarrow$ Curves" tool, we expanded a range of levels, corresponding to Cr-spinel grains and adjusted hues of silicates in order to better distinguish them from each other (Figure 4B). Then, we applied the "Adjustment $\rightarrow$ Gradient map" tool, assigning to the hues of Cr-spinel a rainbow stretch so that most magnesian Cr-spinel were colored by dark blue, while those with most ferrous compositions by red. Then, we attributed to plagioclase, clinopyroxene, and olivine different hues of grey and to sulfides (pure white) (Figure 4C). This algorithm allowed to obtain representative patterns, showing the compositional distribution of $\mathrm{Cr}$-spinel with respect to enclosing silicate phases within a BSE-photographed site and even a whole thin section, mapped by SEM. However, it should be noted that on different images, the same Cr-spinel compositions may be highlighted by different colors. Thus, this method is used for qualitative visualization only and is not applicable for numeric considerations. 

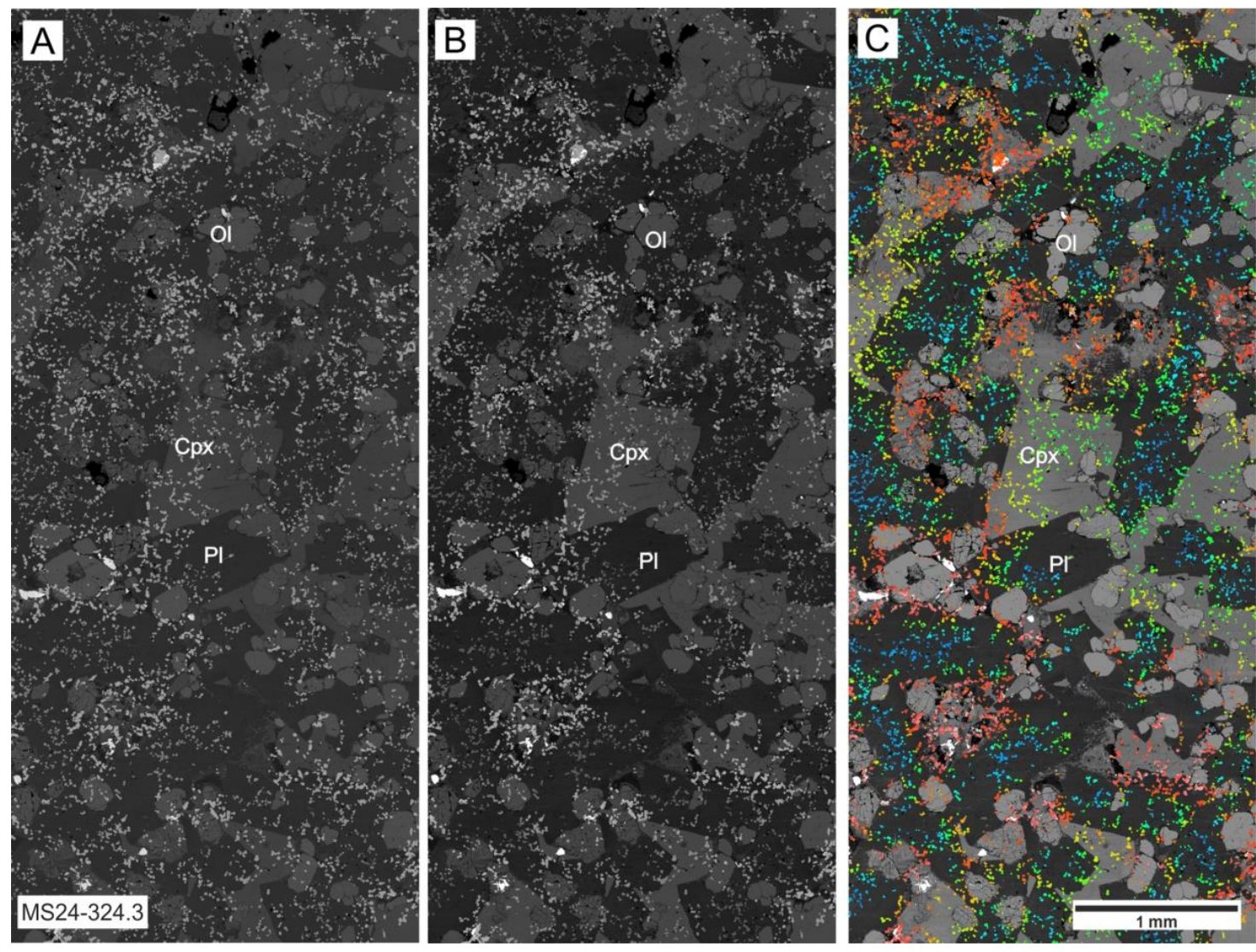

Figure 4. Main stages of a raster BSE (back-scattered electron) photo processing. (A) Initial image;

(B) adjusted grayscale image; (C) pseudocolored image.

\section{Results}

\subsection{Petrography and Textures of the Rocks}

The studied samples are characterized by broadly similar mineral assemblages but highly variable textures. Petrographic features are summarized in the Table 1. In this sub-section we present general textural descriptions of the studied samples, while more detailed descriptions of $\mathrm{Cr}$-spinel textures are presented in the subsequent subsection.

Mineral assemblages are dominated by plagioclase, olivine, and clinopyroxene, along with minor orthopyroxene, phlogopite and apatite. Non-silicate minerals are $\mathrm{Cr}$-spinel, along with minor ilmenite, apatite, sulfides and rare baddeleyite and platinum-group minerals (PGMs).

Primary silicate minerals are significantly altered. Plagioclase is to various extent replaced by albite, sericite, K-feldpar with minor epidote. Patchy alteration of pyroxenes seems to begin with fibrous amphibole (pargasite, ferro-pargasite, hornblende), while chlorite of clinochlore-chamosite series with minor Fe-hydroxides replace both pristine clinopyroxene and secondary amphibole. Olivine is extensively replaced by aggregates, composed by largely magnesian varieties of smectite, serpentine and iddingsite, the presence which is revealed by brownish colors of these aggregates. No fresh olivine was observed in the samples from the Medvezhy Ruchey mine, whereas in the samples from MS- 24 core, there are sites with well-preserved euhedral olivine grains with thin rinds of the secondary aggregates. 
Table 1. Summary of petrographic features of the studied rocks.

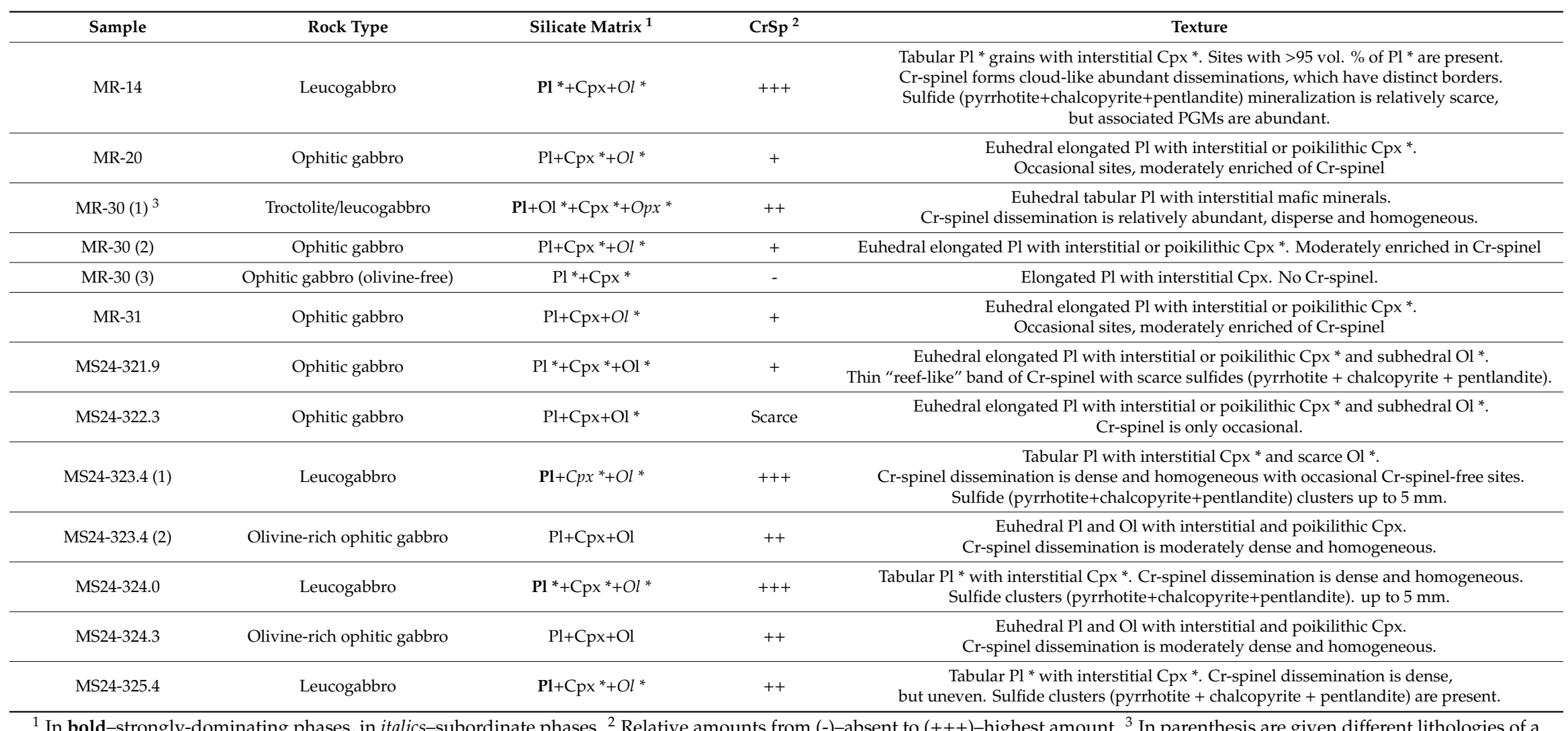

${ }^{1}$ In bold-strongly-dominating phases, in italics-subordinate phases. ${ }^{2}$ Relative amounts from (-)-absent to (+++)-highest amount. ${ }^{3}$ In parenthesis are given different lithologies of a certain sample (see text for details). Asterisks $\left(^{*}\right)$ are used to define strongly altered/replaced silicates. 
A set of samples collected from the Medvezhy Ruchey open pit mine is representative of broad petrographic variations (Table 1) in a restricted volume of the upper zone of the intrusion. The sampling was performed on a small area (see higher) and although exact locations of each sample in the outcrop are missing, these petrographic varieties occur spatially close $(<1-2 \mathrm{~m})$ to each other. The most interesting mineralogical and textural features are observed in the sample MR-14 (Figure 5A). It has an inhomogeneous texture, which is represented by plagioclase segregations set in a matrix of smaller subhedral plagioclase and clinopyroxene crystals. Primary silicates are extensively replaced by secondary assemblages with plagioclase in segregations being totally altered. Former plagioclase grains are euhedral with an elongated and tabular shape, while former clinopyroxene is anhedral and occupies interstices between grains of plagioclase. Olivine is thought to have been present in the assemblage, but it is difficult to determine its initial abundance due to extensive replacement. Cr-spinel (10-200 $\mu \mathrm{m}$ in size) is abundant and is scattered throughout the rock without showing any association with particular silicate minerals. The scattering is uneven and forms clusters without any pronounced specification of their shapes. Distinct boundaries between $\mathrm{Cr}$-spinel-rich and $\mathrm{Cr}$-spinel-free sites of the rock are observed. Ore mineralization is represented by veinlets of pyrite, scarce intermittent pentlandite-pyrrhotite-chalcopyrite assemblages, and various microscopic PGMs, which are tightly associated with pentlandite-pyrrhotite-chalcopyrite clusters.

Sample MR-30 exhibits three types of silicate lithologies, which have clearly defined boundaries between each other (Figure 5B, Table 1) and are of significant interest in the view of the discussion to come. The first lithology (labeled " 1 ") has leucogabbro-troctolite modal composition. It is characterized by relatively fresh tabular plagioclase grains, brownish pseudomorphs after olivine and minor anhedral clinopyroxene and orthopyroxene, that are to variable extents replaced by chlorite-amphibole. Cr-spinel dissemination in this part of the sample is quite dense and homogenous, except for the former olivine, which hosts noticeably lesser amounts of $\mathrm{Cr}$-spinel than plagioclase and clinopyroxene. The second lithology (labeled " 2 ") is used to contain less olivine and plagioclase than the previous one and can be classified as ophitic gabbro. It consists of major tabular plagioclase, interstitial clinopyroxene (both altered extensively), and a lesser amount of pseudomorphs after olivine. Within this lithology Cr-spinel scattering is less abundant and more uneven than within the first one. While the first and second lithologies of the MR-30 sample are different only in terms of texture and modal proportions of minerals and, the third lithological type (labeled " 3 ") is strikingly different from the first and second types. It is dominated by sericitized and albitized plagioclase with minor clinopyroxene, which is replaced by chlorite and fibrous amphibole, and contains no olivine and $\mathrm{Cr}$-spinel, whereas elongated and spiky crystals of ilmenite are abundant. This lithology resembles "ordinary" ophitic gabbros, which compose most of the Main zone Norilsk-1 intrusions. Accessory minerals in sample MR-30 include sulfides (chalcopyrite, pyrrhotite, pentlandite, and pyrite), apatite, ilmenite, and PGMs, which are usually found in association with low-Mg Cr-spinel and sulfides.

Samples MR-20 and MR-31 have more homogenous fabric and texture but lower abundances of Cr-spinel than samples MR-14 and MR-30. They are classified as ophitic gabbro and consist of euhedral plagioclase, subhedral to anhedral clinopyroxene, and pseudomorphs after olivine. The clinopyroxene in sample MR-31 is fresher and sometimes exhibits more euhedral shapes than the clinopyroxene in sample MR-20. However, aggregates of chlorite, amphibole, serpentine, micas, and other hydrous silicates are abundant in these samples, and it is sometimes difficult to distinguish the precursor mineral. Phlogopite, sulfides, apatite, ilmenite, baddeleyite, and PGMs occur as minor phases in both samples. 

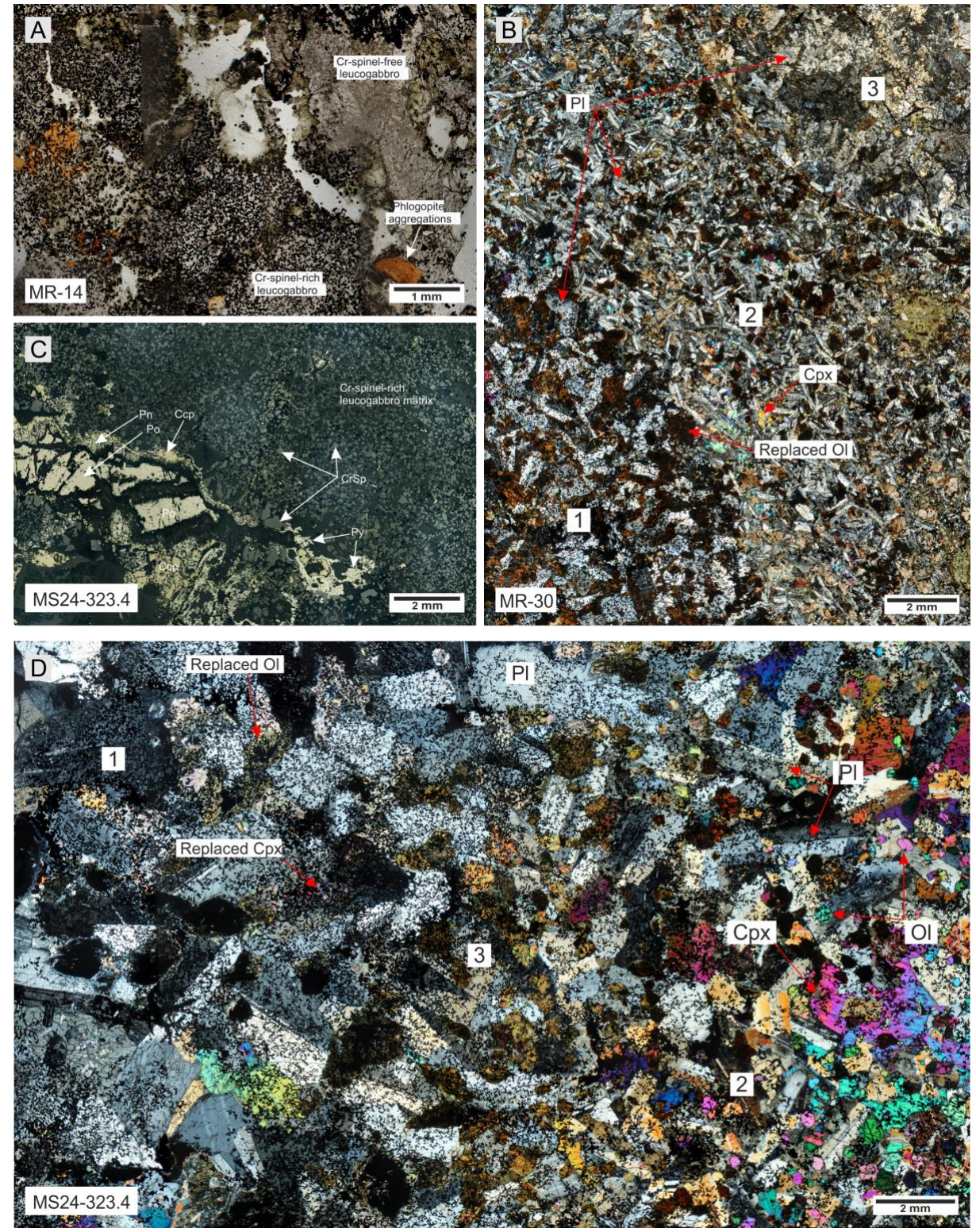

Figure 5. Photomicrographs of the representative thin sections of the studied Cr-spinel-rich rocks: (A) leucogabbro with Cr-spinel-rich clusters (plane polarized light); (B) three lithological domains within MR-30 thin section: troctolite (1), ophitic gabbro (2), and olivine-free ophitic gabbro without Cr-spinel (3) (crossed-polarized light); (C) abundant $\mathrm{Cr}$-spinel dissemination and big sulfide aggregation in leucogabbro (reflected light), (D) leucogabbro (1) and olivine gabbro (2) lithological domains with a transitional zone (3) (cross-polarized light). Mineral abbreviations: Pl-plagioclase; Cpx-clinopyroxene, Ol-olivine; Pn-pentlandite; Po-pyrrhotite; Ccp-chalcopyrite, Py-pyrite, CrSp-chromian spinel.

Samples of MS-24 core exhibit variable textures. In general, the rocks present in the considered section of the core change in the following sequence (top down) (Figure 3):

- Hornfels-like rocks from the contact with the Ivakinskaya suite basalts.

- Breccia-like rocks with leucocratic ophitic gabbro matrix and abundant xenoliths of coal-bearing shales and terrigenous schists,

- Mottled "taxitic" rocks with lithological domains largely represented by leucogabbro, troctolite, and olivine gabbro. Cr-spinel and sulfides are abundant in this part of the core.

- Gabbro- and gabbro-diorites of the main differentiated series. 
Sample MS24-321.9 has ophitic texture with elongated plagioclase grains, strongly altered anhedral clinopyroxene and subhedral olivine. Cr-spinel occurs as a thin reef-like $(\sim 3 \mathrm{~mm})$ band with a significant amount of sulfides and sulfide-PGM assemblages.

Sample MS24-322.5 in thin section is represented by relatively homogeneous ophitic gabbro, consisting of euhedral tabular and prismatic plagioclase grains settled within the matrix, composed of anhedral and poikilithic clinopyroxene and olivine (replaced). $\mathrm{Cr}$-spinel mineralization is scarce and is represented by tiny swarms of grains, which are all hosted by silicates without any mineralogical preference.

Sample MS24-323.4 is completely different from its previous counterpart. Several studied thin sections are dominated by leucogabbro and olivine gabbro (Figure 5C,D). However, leucocratic type of rock (labeled "1" on Figure 5D) seems to be prevalent. It is composed of tabular plagioclase, which is the dominant phase and, in most cases, only slightly affected by albitization and sericitization. Clinopyroxene occurs as interstitial anhedral grains, which are often replaced by chlorite and amphibole. Olivine is present in subordinate amounts and is largely replaced by saponite-talk-serpentine assemblages. The most important feature of this rock type is extremely high content of Cr-spinel and significant, but lesser amounts of sulfides, which form impregnated textures with clusters up to centimeter in their long dimension (Figure 5C). Olivine gabbro (labeled " 2 " on Figure 5D) exhibits quite homogeneous texture and contain moderate enrichments in $\mathrm{Cr}$-spinel and minor sulfides. Within the examined thin section, the boundary between leucocratic and olivine gabbro varieties is less distinct than in the sample MR-30 (Figure 5B,D). Instead, there is a thin transitional zone (labeled " 3 " in Figure 5D) where the rock fabric becomes more fine-grained and plagioclase turns from tabular to elongated, olivine and clinopyroxene abundances increase, while Cr-spinel and sulfide abundances decrease.

Sample MS24-323.4 is completely different from its previous counterpart. Several studied thin sections are dominated by leucogabbro and olivine gabbro (Figure 5C,D). However, leucocratic type of rock (labeled "1" on Figure 5D) seems to be prevalent. It is composed of tabular plagioclase, which is the dominant phase and, in most cases, only slightly affected by albitization and sericitization. Clinopyroxene occurs as interstitial anhedral grains, which are often replaced by chlorite and amphibole. Olivine is present in subordinate amounts and is largely replaced by saponite-talk-serpentine assemblages. The most important feature of this rock type is extremely high content of Cr-spinel and significant, but lesser amounts of sulfides, which form impregnated textures with clusters up to centimeter in their long dimension (Figure 5C). Olivine gabbro (labeled "2" on Figure 5D) exhibits quite homogeneous texture and contain moderate enrichments in $\mathrm{Cr}$-spinel and minor sulfides. Within the examined thin section, the boundary between leucocratic and olivine gabbro varieties is less distinct than in the sample MR-30 (Figure 5B,D). Instead, there is a thin transitional zone (labeled " 3 " in Figure 5D) where the rock fabric becomes more fine-grained and plagioclase turns from tabular to elongated, olivine and clinopyroxene abundances increase, while Cr-spinel and sulfide abundances decrease.

Sample MS24-324.0 is somewhat similar to the leucocratic varieties of MS24-323.4 and is composed of tabular plagioclase grains with interstitial infilling of chlorite and amphibole (former clinopyroxene). It also hosts extremely dense $\mathrm{Cr}$-spinel disseminations, which are scattered without any preference to the type of host silicate and substantial content of sulfide clusters.

Sample MS24-324.3 exhibits features similar to those of olivine gabbro variety of the MS24-323.4. It is the most unaltered sample in the studied set and is characterized by a relatively homogeneous ophitic texture with euhedral olivine and plagioclase and interstitial clinopyroxene. Cr-spinel dissemination is dense but to a lesser extent than in leucocratic samples MS24-323.4 and MS24-324.0. Sulfide clusters and associated PGM mineralization are substantial but, in this study, were not examined in detail.

Sample MS24-325.4 has heterogeneous fabric and texture (Figure 3). Its composition is dominated by plagioclase, which forms crystals of different shape and size: large $(>3 \mathrm{~mm})$ tabular grains and smaller needle-shaped crystals. Clinopyroxene infills narrow interstices between tightly packed plagioclase and forms large poikilithic crystals that enclose the plagioclase grains. Cr-spinel distribution in the studied thin section is uneven and is not as abundant as in the leucocratic and picritic gabbro in 
the above part of the core cut. However, several embayments and trails of $\mathrm{Cr}$-spinel dissemination are quite dense and have distinct boundaries (Figure 6A).
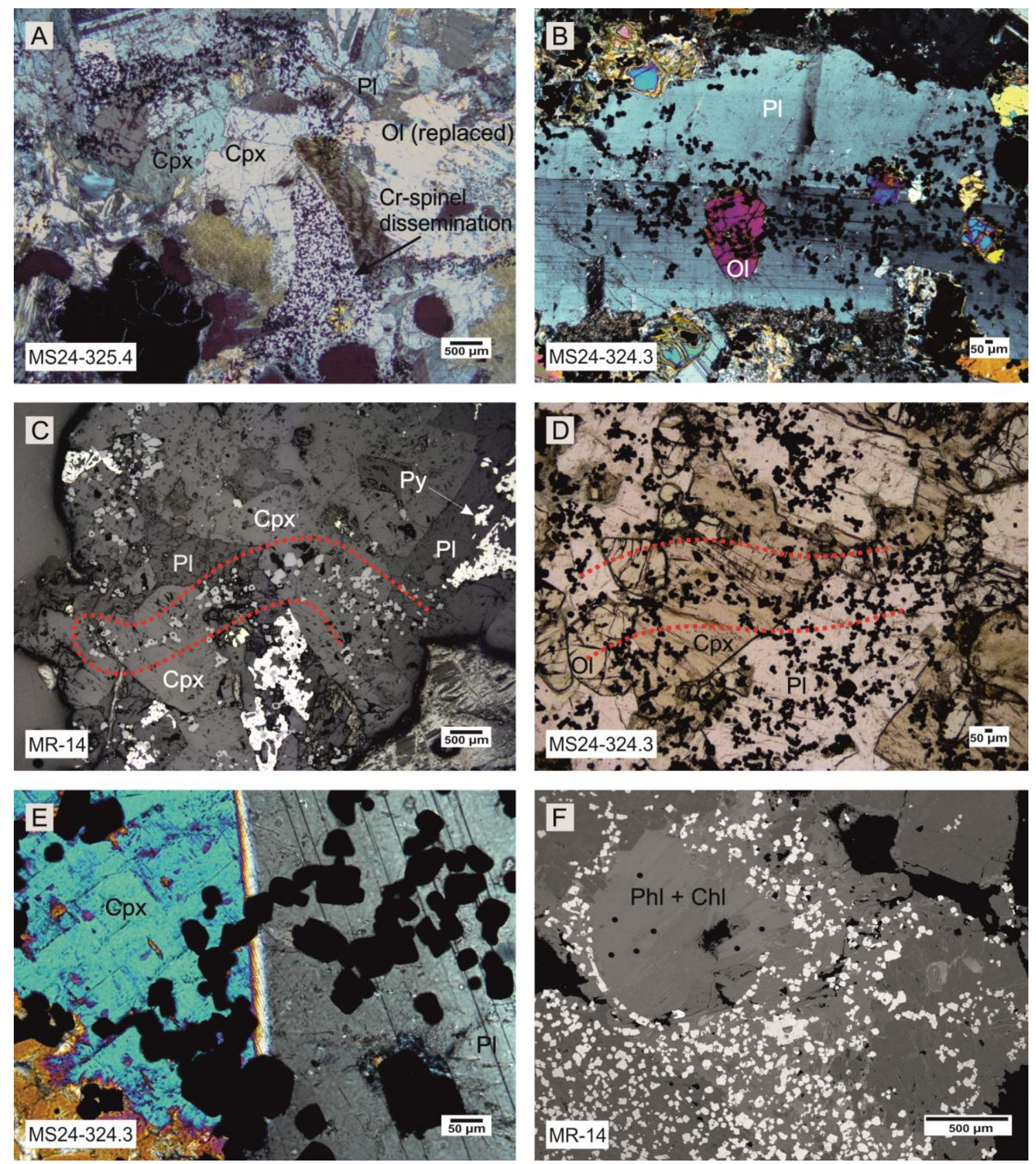

Figure 6. Representative photomicrographs of specific Cr-spinel arrangements in the studied rocks. (A,B) Embayments of Cr-spinel dissemination, passing through the silicates (cross-polarized light); (C,D) Outlined by dashed lines are trails of Cr-spinel, crossing silicate borders (reflected and plane-polarized light respectively), (E) a thin chain of $\mathrm{Cr}$-spinel grains, crossing the border between silicates; (F) sub-circular arrangement of Cr-spinel, surrounding a "bubble" composed by chlorite (Chl) and phlogopite (Phl) (BSE-microphoto). Mineral abbreviations: Pl-plagioclase, Ol-olivine, Cpx-clinopyroxene, Phl-phlogopite, Chl-chlorite.

\subsection{Cr-Spinel: Textures and Morphology}

The main characteristics of $\mathrm{Cr}$-spinel in the studied rocks are their heterogeneity and absence of planar (or reef-like) patterns, typical for layered and differentiated intrusions. Although the abundance 
of Cr-spinel dissemination varies widely (from uneven accessory grains in MS24-322.3 to exceptionally abundant clusters in MR-14 and MS24-323.4), the complexity of grain distribution (e.g., swarms or clusters) is a common feature (Figures 5C and 6A,B). Borders of Cr-spinel-rich clusters often do not coincide with the margins of silicate phases and can either pass through silicate phases or be around them (Figure 6A,B). It is important that borders of Cr-spinel-rich clusters and Cr-spinel embayments passing through several silicate grains may not necessarily change their shape or show any evidence of interruption. Instead, the textures give a visual impression that $\mathrm{Cr}$-spinel grains were interspersed over the pre-existing silicate matrix (Figure 6B). Upon closer inspection, thin trails of Cr-spinel grains pass through the silicates unaffected by the grain boundaries (Figure 6C,D). The most indicative examples of this feature are one-grain-thick chains of $\mathrm{Cr}$-spinel grains, observed near the margins of the silicate phases (Figure 6E). Importantly, these kinds of alignment are not unique for a given sample but are observed in most of the samples studied from both the Medvezhy Ruchey and MS-24 core.

A remarkable textural feature, which is characteristic for the "sulfide-poor" PGE-Cr-spinel-rich lithologies in the Norilsk-type intrusions in general, is a sub-circular alignment of Cr-spinel grains. This is manifested in different locations and samples, and in certain cases it is even termed as bubbleor foam-like textures [32,40]. In our studied samples, there was only one such Cr-spinel "bubble," infilled with phlogopite and chlorite, found in sample MR-14 (Figure 6F). However, well-developed sub-circular arrangements of Cr-spinel are observed on a small scale in several samples both from the Medvezhy Ruchey mine and MS-24 core. In samples MS24-323.4 and MS24-324.3, these circles are so abundant that they should be considered as a common type of $\mathrm{Cr}$-spinel distribution. In contrast to the previous reports of these textures, this kind of alignment does not show affiliation to phase boundaries and cannot be considered as bona fide agglutination of $\mathrm{Cr}$-spinel on pre-existing silicates or bubbles (Figure 7). The arising problem is of importance and will be exploited in more detail below.
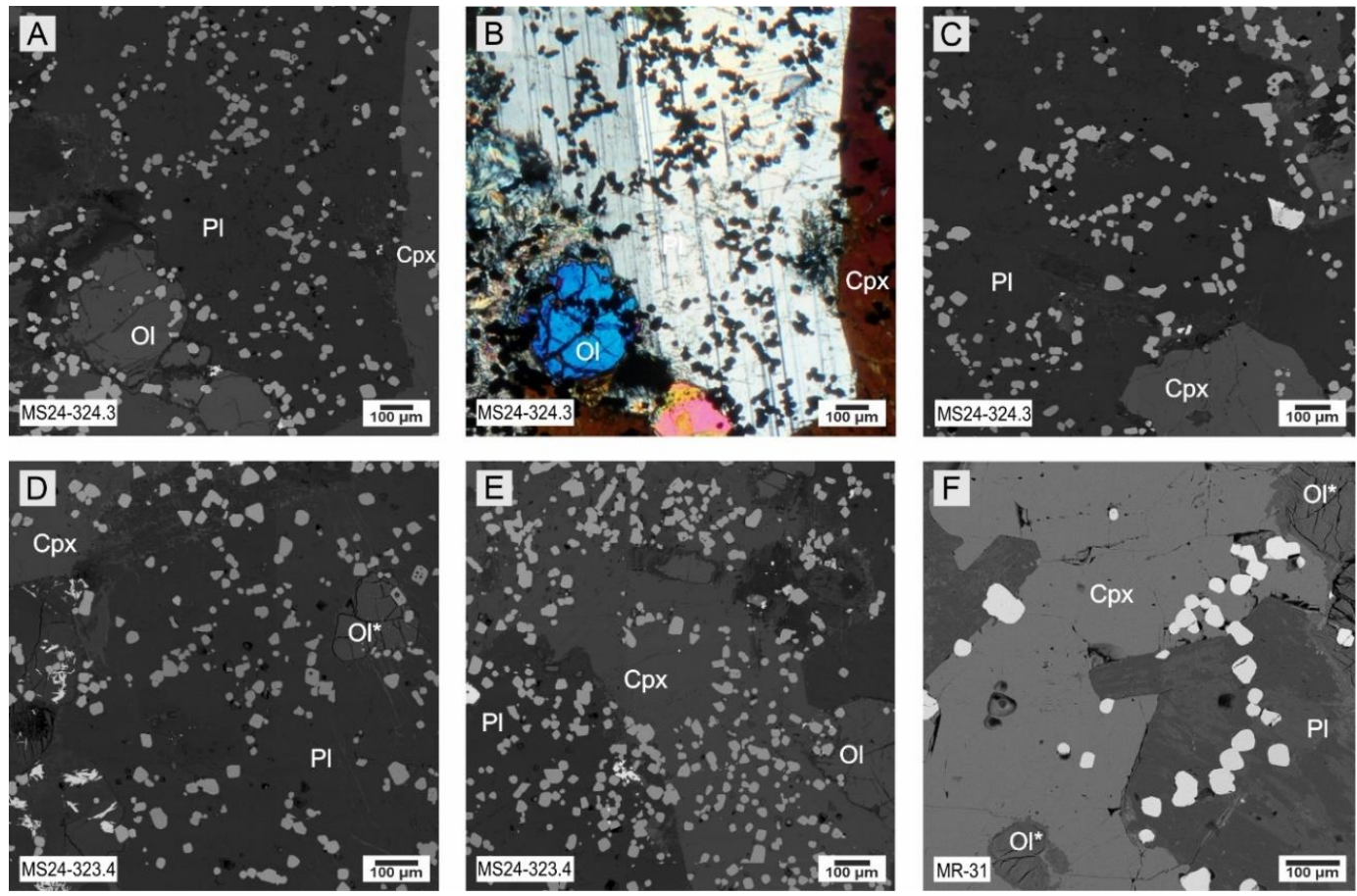

Figure 7. Sub-circular arrangements of Cr-spinel, hosted by unaltered silicates. (A,C-F) SEM BSE photo; (B) transmitted, cross-polarized light. Mineral abbreviations: Pl-plagioclase, Ol-olivine, Cpx-clinopyroxene, abbreviations followed by an asterisk $\left(^{*}\right)$ label strongly altered and replaced silicates.

In terms of morphology, Cr-spinel varies from small $(10-80 \mu \mathrm{m})$ rounded grains (Figure $8 \mathrm{~A})$ to bigger (up to $200 \mu \mathrm{m}$ ) straight-edged subhedral crystals (Figure 8B,C). Importantly, the former are mostly isolated, while the latter tend to agglomerate within tightly-packed intergrowths (Figure 8C). 
For the purpose of discussion, we address small rounded Cr-spinel grains as Cr-spinel-1 and bigger, often intergrown grains, as Cr-spinel-2. However, it should be kept in mind that these morphological types are rather end members of a continuous range than distinct populations. Chemical examination of Cr-spinel revealed that Cr-spinel-1 grains are richer in $\mathrm{Mg}$ and $\mathrm{Al}$ and poorer in Fe and $\mathrm{Ti}$ than Cr-spinel-2 (see the next section for the details) (Figure 8D,E). Cr-spinel-2 is often found in intergrowths with ilmenite (Figure 8C) and may contain ilmenite inclusions or lamellae.
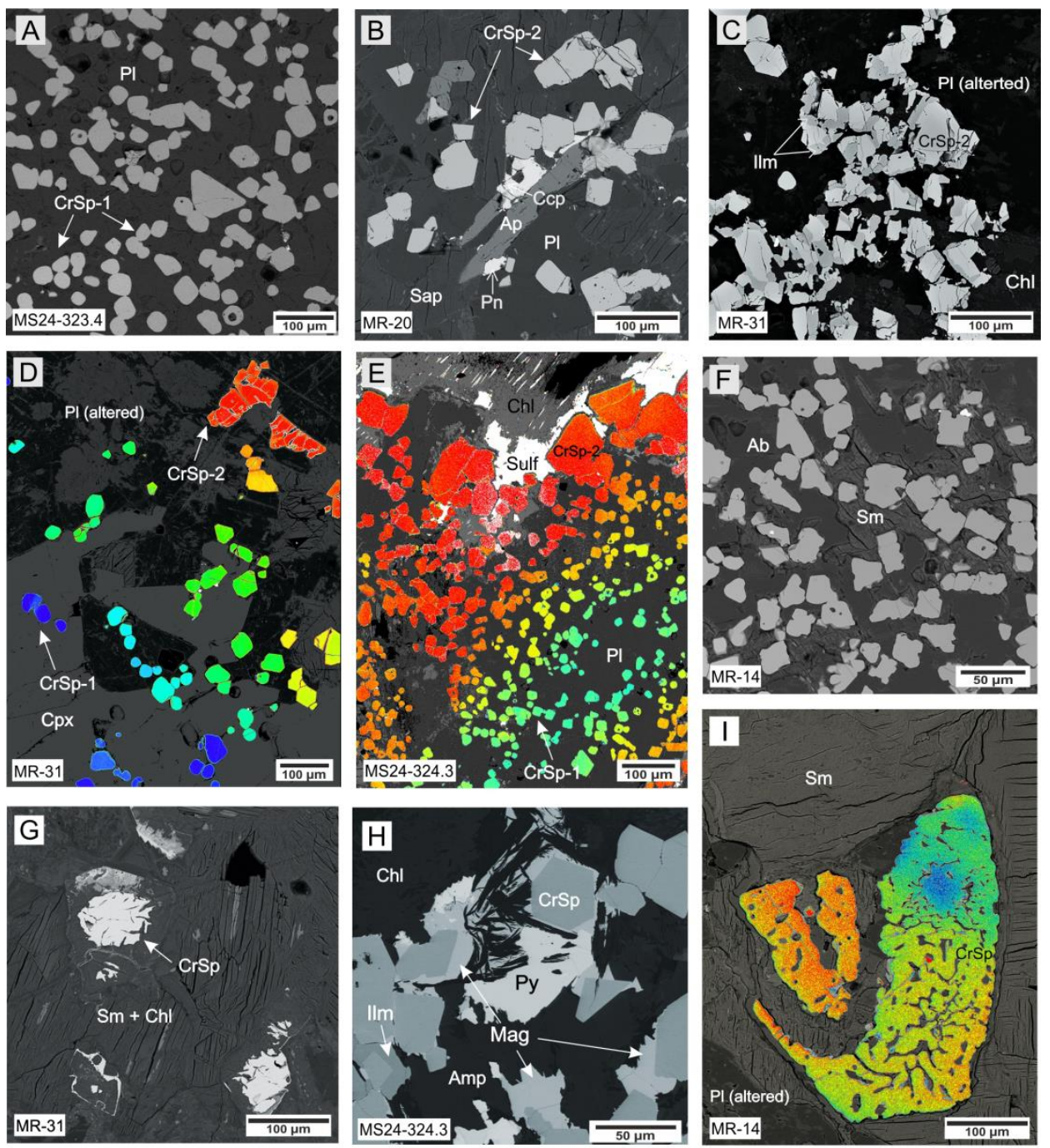

Low $\mathrm{Mg}$
Low Al
High Fe (total)

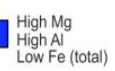

Figure 8. A variety of Cr-spinel morphologies. (A-D)-SEM BSE photos; (E-G) colored SEM BSE photos (see Methods and data processing); (H,I) SEM BSE photos. Mineral abbreviations: Pl-plagioclase, Ol-olivine, Cpx-clinopyroxene, Sulf-sulfide, Ccp-chalcopyrite, Pn-pentlandite, Apapatite, Sm-smectite, $\mathrm{CrSp}$-chromian spinel, Ilm-ilmenite, Chl-chlorite, Mag-magnetite, Amp-amphibole.

Aside from these commonly present Cr-spinel morphologies, there are some rare morphological types that occur in strongly altered silicates. Those include jigsaw-edged grains in sericitized plagioclase (Figure 8F) and strongly resorbed grains in extensively altered sites of the rocks (Figure 8G). Occasionally found are $\mathrm{Cr}$-spinel grains, overgrown by magnetite (Figure $8 \mathrm{H}$ ) and a symplectite-like compositionally heterogeneous intergrowth of $\mathrm{Cr}$-spinel in smectite pseudomorph after olivine (Figure 8I). In addition, up to $20 \%$ modal of $\mathrm{Cr}$-spinel grains may contain rounded silicate inclusions, which mainly comprise major orthopyroxene, phlogopite, amphibole, chlorite, and silicate glass. Those inclusions were 
considered to be a heterogeneously trapped mixture of melt and solid phases and are studied in detail in [41].

\subsection{Cr-Spinel: Chemistry}

We obtained a large dataset of Cr-spinel compositions (over 4000 analyses), which is listed in Table S1. Figure 9 plots the obtained compositions of $\mathrm{Cr}$-spinel and reference data for layered intrusions worldwide and intrusive and effusive rocks of the Norilsk region of the Siberian large igneous province (LIP) (objects are specified, and data sources are listed in the figure caption).
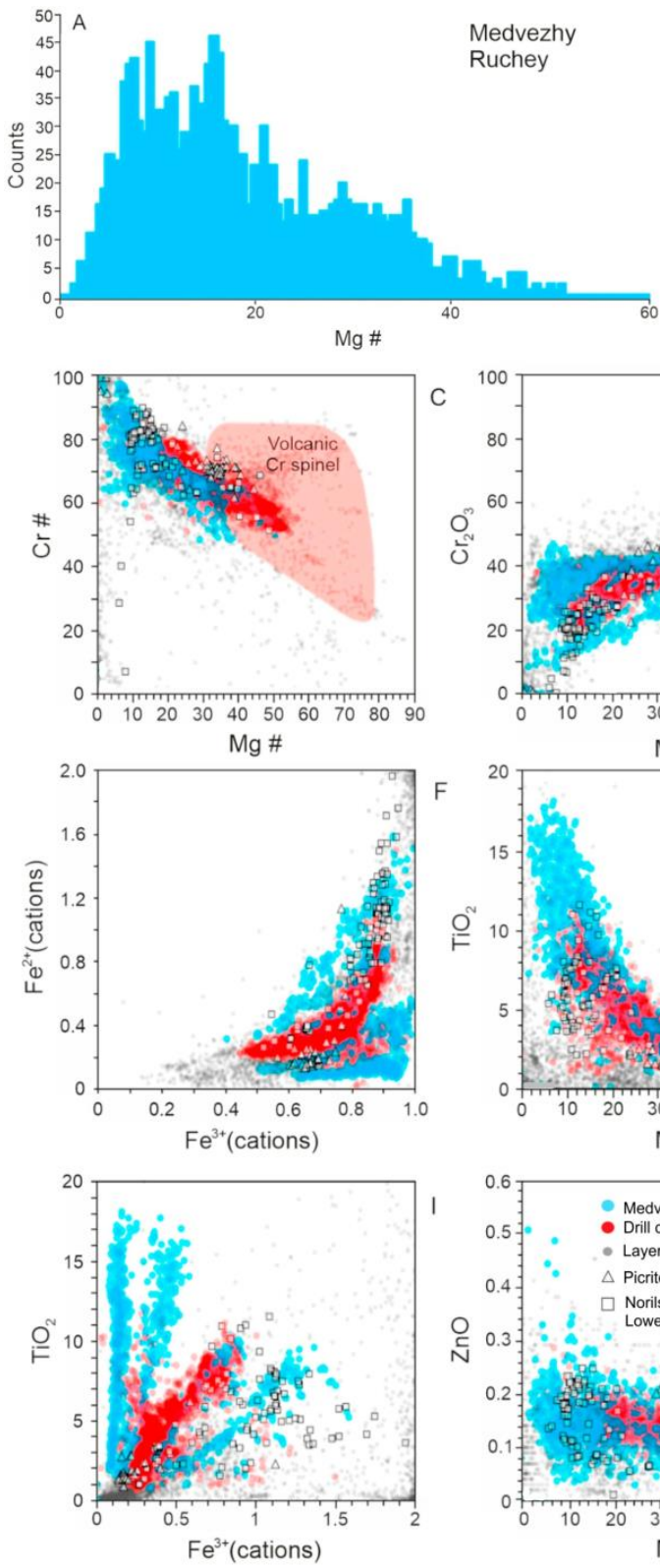
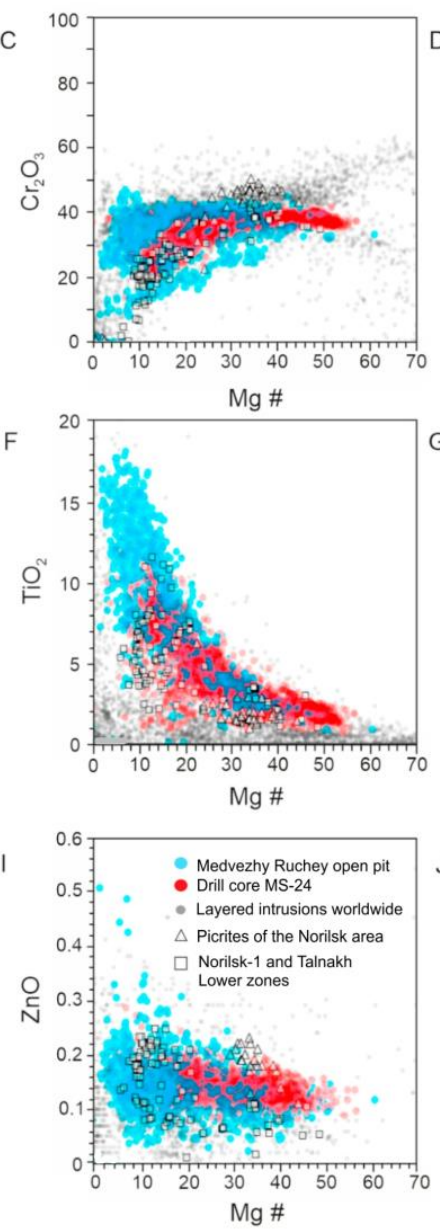

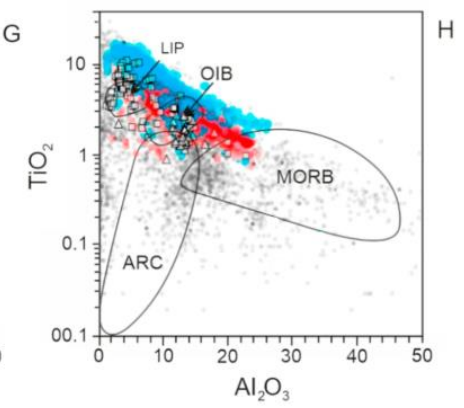

MS-24
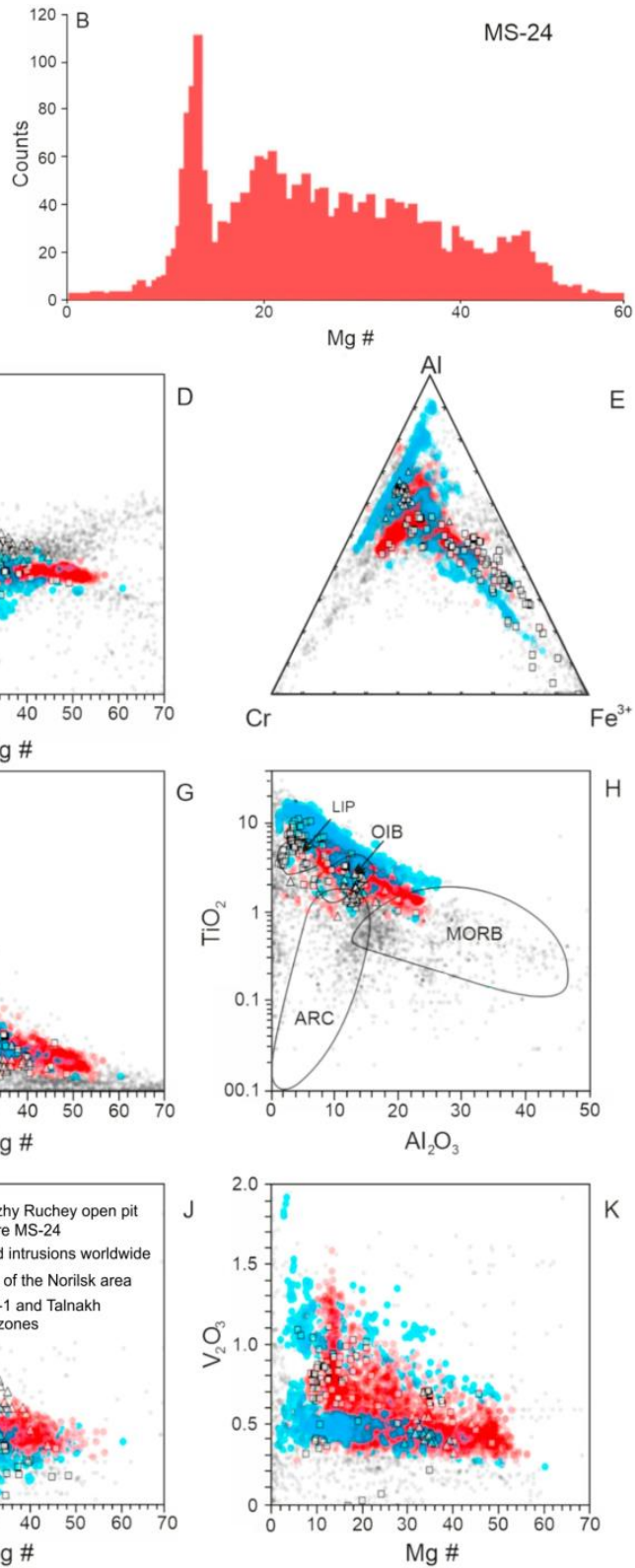

Figure 9. Major- (A-I) and minor-element $(\mathbf{J}, \mathbf{K})$ element variations in Cr-spinel from rocks of Medley riches open pit and drill core MS-24. Compositions for layered intrusions worldwide are from [42], Gudchikhinsky and Tuklonsky picrites [34,43-45] Cr-spinel from Norilsk-1 and Talnakh Lower zones from [46]. Fields for LIP (large igneous provinces), OIB (ocean island basalts), MORB (mid-oceanic ridge basalts) and Arc basalts on the inset $(\mathbf{H})$ are as in [47]. 
In all studied samples, Cr-spinel compositions are characterized by generally low $\mathrm{Mg \#}$ $\left(\mathrm{Mg} /\left(\mathrm{Mg}+\mathrm{Fe}^{2+}\right)\right.$ mol. \%) (2 to 55 mol. \%) (Figure 9A,B) and medium to high $\mathrm{Cr} \#(\mathrm{Cr} /(\mathrm{Cr}+\mathrm{Al}) \mathrm{mol} . \%)$ (48-95 mol. \%). The most abundant Cr-spinel population has Mg\# between 10-20 mol. \%, while Cr-spinel with Mg\# exceeding 45 mol. \% is quite uncommon, especially for rocks from the Medvezhy Ruchey (Figure 9A). The analyzed Cr-spinel grains shows a negative correlation between $\mathrm{Cr \#}$ and $\mathrm{Mg \#}$ (Figure 9C) and various behavior of $\mathrm{Cr}_{2} \mathrm{O}_{3}$ content. The $\mathrm{Al}_{2} \mathrm{O}_{3}$ content in $\mathrm{Cr}$-spinel varies broadly from 1 wt. \% to 26 wt. \% (Figure $9 \mathrm{H}$ ), forming a positive linear correlation with Mg\#. Broad ranges are observed in the $\mathrm{Al}-\mathrm{Cr}-\mathrm{Fe}^{3+}$ triple variations-the compositional field of the studied Cr-spinel overlaps with significant part of $\mathrm{Cr}$-spinel compositions from intrusive rocks (Figure 9E) A characteristic feature of $\mathrm{Cr}$-spinel in all the examined samples is elevated $\mathrm{TiO}_{2}$ content, which varies significantly in grains with different $\mathrm{Mg \#}$ and reaches maximum of about $18 \mathrm{wt}$. \% in Cr-spinel with the lowest Mg\# values (Figure 9G). In general, Cr-spinel from all the samples observed exhibits anomalously broad chemical variations. The obtained chemical ranges overlap with $\mathrm{Cr}$-spinel compositions from intrusive complexes worldwide, while in terms of $\mathrm{Ti}^{-} \mathrm{Fe}^{3+}$ systematics a large amount of the obtained compositions does not have analogues elsewhere in the world (Figure 9I). They also fully overlap with compositional fields of Cr-spinel from the Lower zone of Norilsk-type intrusions and from the effusive series from the Western part of the Siberian LIP (Figure 9), being much broader than the latter ones. In addition, chemistry of the studied Cr-spinel does not correspond to any group with respect to tectonic settings, overlapping with fields of spinels from LIPs, ocean island basalts (OIBs), and even mid-oceanic ridge baslts MORBs (Figure 9H). The abundances of minor elements in the analyzed $\mathrm{Cr}$-spinel, such as $\mathrm{ZnO}, \mathrm{NiO}$, and $\mathrm{V}_{2} \mathrm{O}_{3}$, are slightly elevated compared to typical values for magmatic Cr-spinel [42]. The compositional range for $\mathrm{ZnO}(0.05 \%$ to $0.35 \% \mathrm{wt}$.) shows overlap between all studied samples (Figure 9J). Vanadium contents are more variable and show a slight increase with decreasing Mg\# (Figure 9K). In Cr-spinel from MS-24 drill core, $\mathrm{V}_{2} \mathrm{O}_{3}$ content varies in the same range (0.4-1.3 wt. \%) for all studied samples, $\mathrm{Cr}$-spinel from Medvezhy Ruchey exhibits different $\mathrm{V}_{2} \mathrm{O}_{3}$ contents for different samples. Cr-spinel grains in samples MR-20 and MR-31 have the lowest $\mathrm{V}_{2} \mathrm{O}_{3}$ (0.4 to 0.6 wt. \%) content, whereas $\mathrm{Cr}$-spinel from sample MR-14 have distinctly higher concentrations (0.9-1.5 wt. \% $\left.\mathrm{V}_{2} \mathrm{O}_{3}\right)$.

A striking feature of $\mathrm{Cr}$-spinel investigated is pronouncedly variable systematics of $\mathrm{Cr}, \mathrm{Fe}^{3+}$ and Ti. These differences are especially representative in Cr-spinel from the Medvezhy Ruchey samples and to a lesser extent in rocks from the MS-24 drill core. $\mathrm{Cr}_{2} \mathrm{O}_{3}$ content may either decrease with decreasing Mg\# or remain stable, still reaching 40-45 wt. \% when Mg\# falls down below 10 mol. \% (Figures 9D and 10A,B). Difference in $\mathrm{Fe}^{3+}$ systematics is reflected in divergent trends observed in the $\mathrm{Fe}^{2+}$ vs $\mathrm{Fe}^{3+}$ and $\mathrm{Fe}^{3+}$ vs $\mathrm{TiO}_{2}$ covariations (Figures 9F and 10C-F). Cr-spinel from samples MR-14, MR-30 and MS24-324.0, which are dominated by leucogabbro/troctolite lithologies, is characterized by weak or no change in $\mathrm{Fe}^{3+}$ with $\mathrm{Fe}^{2+}$ growth while $\mathrm{TiO}_{2}$ concentration increases sharply ("ulvospinel" trend). Meanwhile, samples with less leucocratic modal compositions show variably pronounced positive correlation between $\mathrm{Fe}^{2+}$ and $\mathrm{Fe}^{3+}$ contents and not so sharp $\mathrm{TiO}_{2}$ increase ("Ti-magnetite" trend) (Figure 10C-F). In this regard, remarkable is sample MS24-324.3, in the examined sections of which both leucogabbro and olivine gabbro are present (Figure 5D). In the same thin section of this sample Cr-spinel from leucogabbro and from olivine gabbro exhibit diverse trends in terms of $\mathrm{Cr}$, Ti and $\mathrm{Fe}^{3+}$ (Figure 10B,C). 

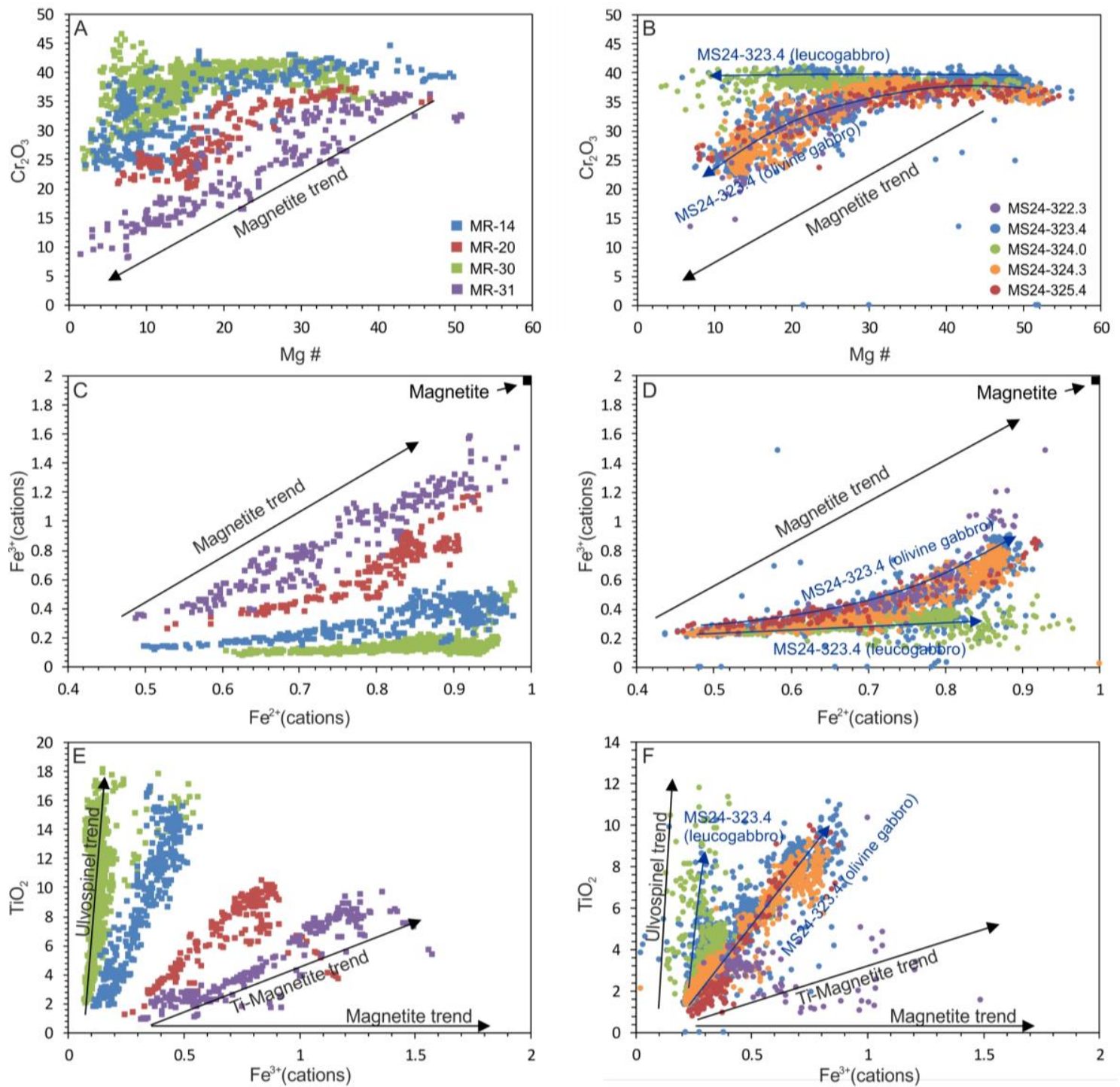

Figure 10. Distinct compositional trends for Cr-spinel from different samples. (A,C,E) Medvezhy Ruchey samples; (B,D,F) drill core MS-24.

On a scale of a given silicate lithology, the composition, morphology, and spatial distribution of Cr-spinel grains are statistically related with each other. Rounded grains (Cr-spinel-1) have higher $\mathrm{Mg \#}, \mathrm{Al}_{2} \mathrm{O}_{3}$ and sometimes $\mathrm{Cr}_{2} \mathrm{O}_{3}$ values compared to intergrown subhedral straight-edged grains (Cr-spinel-2). The latter are characterized by low $\mathrm{Mg \# ,} \mathrm{high} \mathrm{FeO}$ (total) and high $\mathrm{TiO}_{2}$ values . This dependence is well-illustrated by transition zones between locations with high-Mg\# and low-Mg\# grains of Cr-spinel-1 and Cr-spinel-2, respectively (Figure 8D,E). With regard to spatial distribution of the $\mathrm{Cr}$-spinel grains of different compositions, we must emphasize that broad variation of $\mathrm{Cr}$-spinel compositions may be observed at a sub-millimeter scale or even within a single intergrowth. BSE mapping of the studied thin sections with subsequent graphical processing (see Samples and methods) reveals patchy compositional distribution within $\mathrm{Cr}$-spinel disseminations (Figure 11), where Cr-spinel composition is clearly dependent on the type of host silicate phase. 

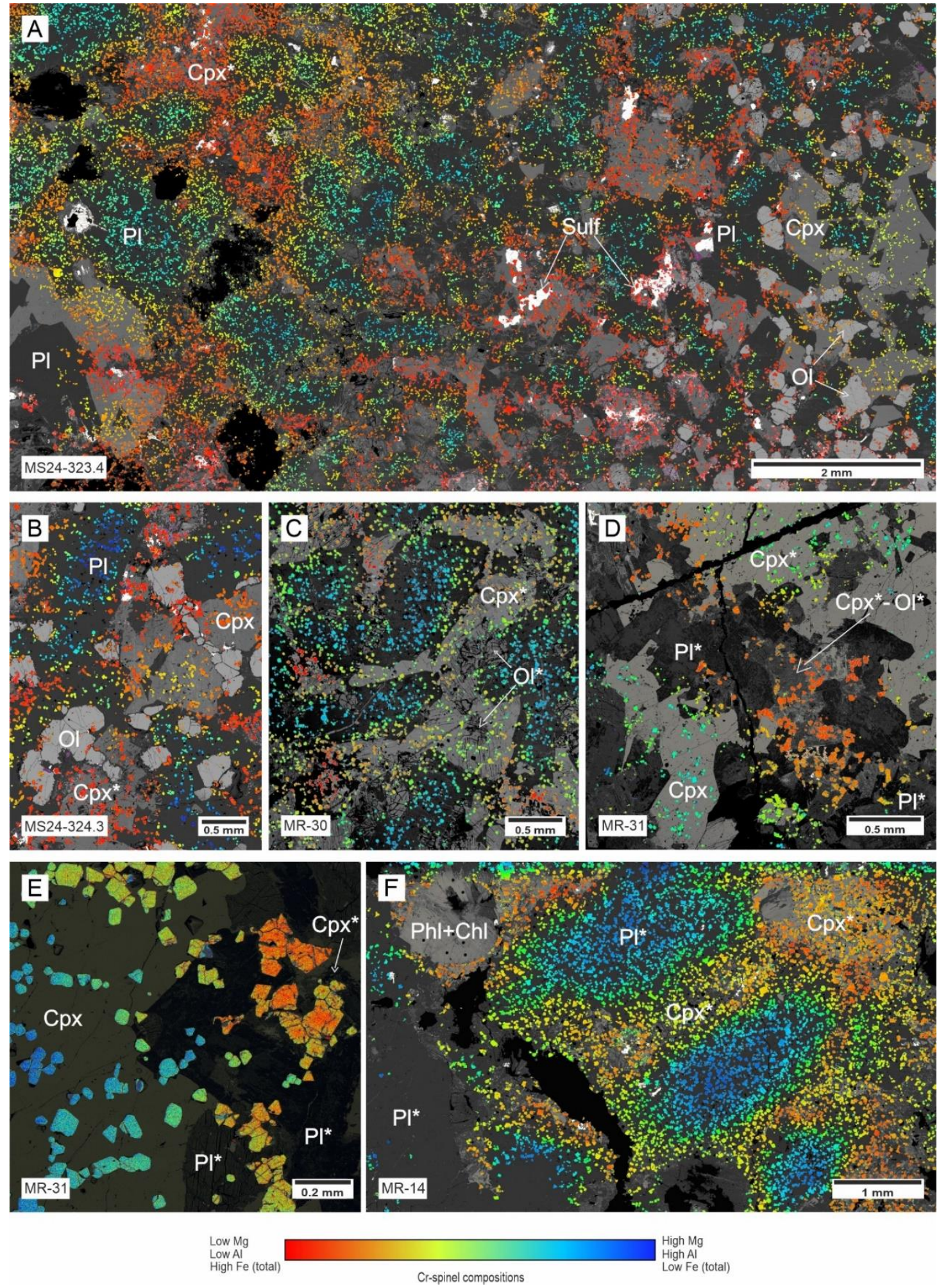

Figure 11. Colored BSE photos, revealing patchy distribution of Cr-spinel compositions in poorly-altered rocks and their dependence on enclosing silicate (see Methods and data processing for the technique of coloring). (A,B)-patchy pattern in weakly-altered silicate matrix. (C-E)-patterns in moderately-altered rocks with more magnesian $\mathrm{Cr}$-spinel associated with fresh silicates. (F)-patchy pattern in strongly altered leucogabbro. Mineral names abbreviations: Pl-plagioclase, Ol-olivine, Cpx-clinopyroxene, Sulf-sulfide, Chl-chlorite, Phl-phlogopite, abbreviations followed by an asterisk $\left.{ }^{*}\right)$ label strongly-altered or fully-replaced silicates. 
Compositional differences in $\mathrm{Cr}$-spinel enclosed in fresh plagioclase, clinopyroxene, and olivine are statistically derived (Figure 12A-C). With some regard to a given sample and sampling location, Cr-spinel grains hosted by plagioclase are characterized by the highest $\mathrm{Mg \#}$ with the main mode of about 45-50 mol. \% Mg\# of Cr-spinel, enclosed within clinopyroxene varies generally in range 20-40 mol. \%, while those of rare Cr-spinel grains enclosed in unaltered olivine do not exceed 20 mol. $\%$ with a single grain with Mg\# 31 mol. \% (Figure 12A-C). In contrast, Cr-spinel hosted by altered silicates show very similar modes of Mg\# (12-17 mol. \%) and it is clearly seen that both in replaced plagioclase and clinopyroxene $\mathrm{Cr}$-spinel loses $\mathrm{Mg}$ content with respect to grains, settled in fresh silicates. In a perspective of the coming discussion, it is important that despite similar main Mg\# modes of Cr-spinel from replaced silicates, $\mathrm{Cr}$-spinel from replaced plagioclase still appears to have a significant population with Mg\# values higher than 20, while it is not the case for Cr-spinel from replaced clinopyroxene (Figure 12D,E).
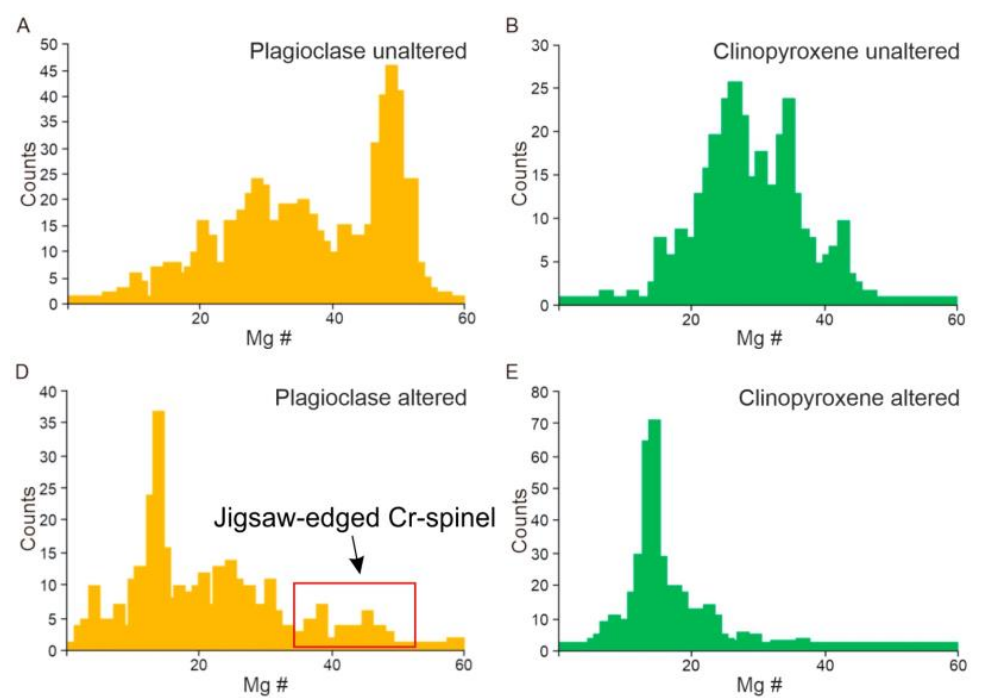
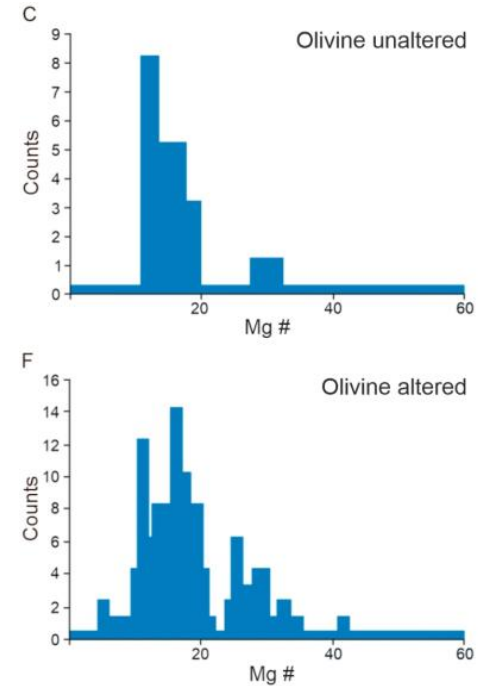

Figure 12. Histograms, representing distribution of $\mathrm{Mg} \#$ values in $\mathrm{Cr}$-spinel enclosed in different kinds of silicates. Host silicate phases for the histograms (A-F) are specified in the captions of each chart.

These numerically-derived patterns are well-illustrated by the pseudocolored images. The freshest samples, MS24-324.3 and MS24-323.4, exhibit a clear patchy pattern with the most magnesian-rich $\mathrm{Cr}$-spinel being enclosed in the inner parts of plagioclase and less magnesian-rich in clinopyroxene and olivine. The least magnesian Cr-spinel is enclosed by altered clinopyroxene and olivine. (Figure 11A,B) A similar distribution is characteristic for the troctolitic assemblage in sample MR-30, where relatively fresh plagioclase hosts magnesian $\mathrm{Cr}$-spinel, while extensively altered clinopyroxene contains more ferrous varieties (Figure 11C). A different pattern can be seen in the MR-31, where slightly-altered clinopyroxene hosts moderately-magnesian Cr-spinel, whilst coalescent grains of low-Mg\# Cr-spinel are associated with sites composed by strongly altered former plagioclase, clinopyroxene and olivine (which actually exhibit aggregates of secondary minerals: chlorite, albite, serpentine) (Figures 8D,E and $11 \mathrm{D}, \mathrm{E})$. Although in most cases intense alteration of the silicates tends to smoothen the compositions of enclosed Cr-spinel grains (Figure 12D,E), it is not the case for the strongly altered sample MR-14, in which differences between Cr-spinel within sericite-albite-feldspar (former plagioclase) and chlorite-amphibole (former pyroxene) aggregates are obvious. While former-pyroxene-hosted Cr-spinel is ferrous and complies with the general regularity, former-plagioclase hosts jigsaw-shaped grains, which are still Mg-rich, reaching up to 50 mol. \% Mg\# (Figures 8F, 11F and 12D).

The behavior of trivalent cations in $\mathrm{Cr}$-spinel seems to not be governed by the enclosing phase as strongly as $\mathrm{Mg}-\mathrm{Fe}^{2+}$ systematics (Figure 13). Both plagioclase and clinopyroxene enclose Cr-spinel with affinities for different $\mathrm{Fe}^{3+}$ trends (Figure 13B,E). It seems that $\mathrm{Cr}$-spinel hosted by altered silicates 
have generally higher $\mathrm{TiO}_{2}$ content, than $\mathrm{Cr}$-spinel enclosed in fresh silicates, while $\mathrm{TiO}_{2}$ concentration in Cr-spinel hosted by altered plagioclase is generally lower than in varieties hosted by altered clinopyroxene (Figure 13C,F). However, it should be noted that since there is no sample where a full set of enclosing phases is well represented, these subtle differences should be treated with care because the statistics can be strongly affected by sample-dependent differences of trivalent cations systematics (see above).
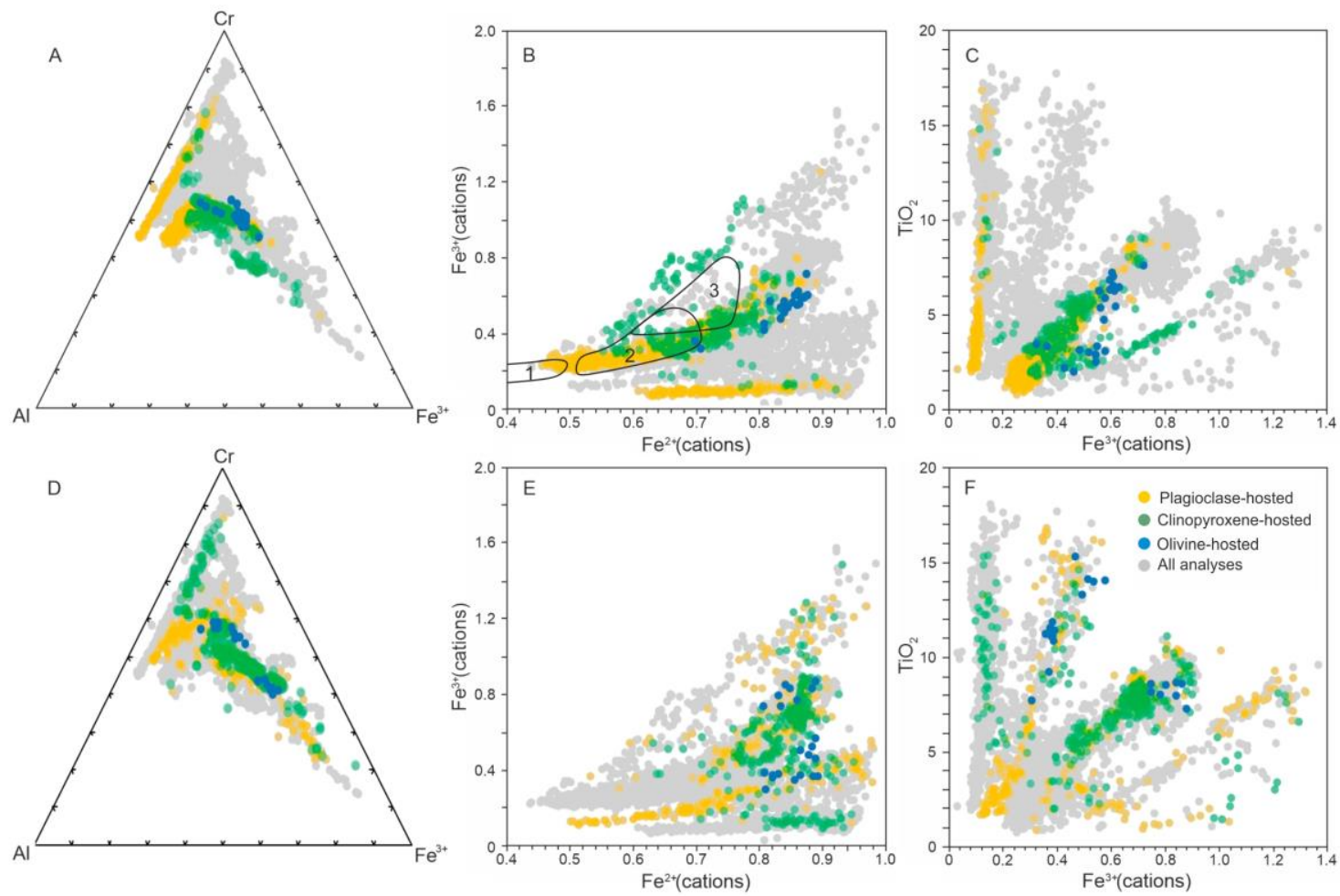

Figure 13. Relationships of trivalent cations and $\mathrm{Ti}$ in Cr-spinel hosted by fresh $(\mathbf{A}-\mathbf{C})$ and altered (D-F) silicates. On inset (B) numbered are fields from [48], which correspond to: compositions of primitive (quenched) Cr-spinel (1), Cr-spinel in olivine after 20 years of equilibration (2) and Cr-spinel in contact with basaltic groundmass after $\sim 20$ years of equilibration (all analyses were performed on Cr-spinel inclusions in olivine from Kilauea Iki Lava Lake, Hawaii).

\section{Discussion}

\subsection{Cr-Spinel Accumulations and Their Compositional Controls: Existing Models}

There are numerous models regarding the origin of $\mathrm{Cr}$-spinel-rich assemblages in mafic-ultramafic complexes. The main concern is that $\mathrm{Cr}$ is a minor element even in most primitive melts, which renders the notion of mass precipitation of $\mathrm{Cr}$-spinel during magma evolution difficult to reconcile [1]. However, there are several models which discuss the formation of Cr-spinel under specific circumstances.

For layered and differentiated magmatic complexes, direct settling of the crystals from crystallizing magma [5], magma replenishment and emplacement of a new pulse of magma [49] or crystallization of Cr-spinel at the bottom of the magma chamber [20] were suggested as potential mechanisms of in situ crystallization. Sweeping down density currents and emplacement of crystal slurries $[16,22,50,51]$ were proposed as gravitation-driven mechanisms for the Cr-spinel-rich "reefs" formation. Additionally, silicate-oxide liquid immiscibility was suggested to play a key role in formation of massive chromitites [52,53]. Several models imply specific physical-chemical circumstances which promote rapid and mass Cr-spinel precipitation. One such model favors a decompressional shift of 
Cr-spinel and olivine liquidus, causing Cr-spinel crystallize alone, without olivine [18,54,55]. Some researchers $[27,56,57]$ have suggested that it was a mixing of primitive magma with partial melts of the wall rocks, which increased the silica content and expanded the field of Cr-spinel stability. Models, implying mixing of primitive melts with fractionated residual magma $[1,56]$ or with alkaline and reduced fluids $[58,59]$ were also proposed to be potential candidates for a number of suites. Furthermore, it was supposed that ophiolitic and alpine chromitites could have formed due to the reaction of a reduced fluid with "magmatic liquid" at $1000-1050{ }^{\circ} \mathrm{C}[60,61]$ or were produced by reactions between orthopyroxene and alkali-basaltic melt [62]. In support of the key role of late-magmatic process, [63] deemed that percolation and infiltration of evolved interstitial melts and fluids through semi-consolidated cumulates may drive element re-distribution, thereby producing Cr-rich "reefs." This theory was adopted in recent studies of [64], who proposed a similar kind of mechanism for the formation of Merensky reef and experimentally approved by [65]. Finally, there are some views that favor metasomatic, pneumatolytic, or hydrothermal processes as essential contributors to the formation of PGE-bearing chromitites in the Ural-Alaskan-type complexes [66-68], ophiolites [69,70] and Cr-spinel-rich skarns of the Talnakh intrusion (Norilsk ore junction) [71]. Thus, there is a huge variety of different processes, which can be involved in formation of $\mathrm{Cr}$-spinel accumulations.

Regardless of the process responsible for the primary $\mathrm{Cr}$-spinel mineralization, it is widely accepted that $\mathrm{Cr}$-spinel composition is strongly affected by post-crystallization modification. Various processes are supposed to affect chemistry of pre-cursor Cr-spinel.

1. Examples of Kilauea Iki and Makaopuhi lava show that even several years are sufficient for Cr-spinel to equilibrate with an evolving melt [48,72]. Cr-spinel entrapped within olivine represents initial compositions only in quenched scoria of the lava lakes, while in rocks sampled from other locations, $\mathrm{Cr}$-spinel grains are systematically higher in $\mathrm{Fe}^{2+} \mathrm{Fe}^{3+}$ and Ti values and lower in $\mathrm{Mg}, \mathrm{Al}$, and $\mathrm{Cr}$ [48].

2. It is commonly accepted that processes of post-cumulus modification of Cr-spinel occur in differentiated intrusions. The major mechanisms include both diffusional equilibration of Cr-spinel with interstitial melts in 'mesocumulate' and 'orthocumulate' environments $[73,74]$ and cation interchange with the host minerals $[75,76]$.

3. A less likely possibility is post-magmatic, metamorphic, and hydrothermal alteration of $\mathrm{Cr}$-spinel. Recent studies, however, provided clear evidence that even low-grade metamorphism may dramatically affect compositions of $\mathrm{Cr}$-spinel, shifting it towards more ferrous, ferric, and Zn-rich compositions [77-80]. In addition, extensive re-deposition of Cr-spinel is thought to occur during various hydrothermal and metasomatic processes [12,67-70], while experimental studies advocate significant mobility of $\mathrm{Cr}$ in fluids [81,82].

\subsection{In-Situ Crystallization of Cr-Spinel and Enclosing Silicates: Textural Evidence}

In order to place constraints on the origin of $\mathrm{Cr}$-spinel accumulations, we first exploit petrographic and textural features of the studied rocks and $\mathrm{Cr}$-spinel mineralization. Despite the absence of clear-cut contact between the intrusion and Ivakinskaya suite basalts and compositional similarities between dolerites of the intrusion and high-T metamorphic rocks formed after the basalts in the contact areas [36], the ophitic textures of the studied rocks and their resemblance to dolerites (Figure 4B) strongly suggest magmatic crystallization as the initial stage of rocks' formation. Petrographic and mineralogical heterogeneity of the studied rocks was also highlighted by previous studies as a typical feature of Upper zones of Norilsk-type intrusions [35]. Different lithologies occurring even within a single hand sample (Figure 3) has been attributed to magma heterogeneity and immiscibility [32] or to entrapment of xenoliths of previously crystallized lithologies [83]. However, considering smooth outlines of these mingling-like textures (Figure 3) and, in certain cases, gradual transition between different lithologies (Figure 5D), we favor the idea of magma heterogeneity and envisage existence of different immiscible (or semi-immiscible) magmas. 
In addition to these petrographic implications, textures of $\mathrm{Cr}$-spinel-rich lithologies provide further insights into crystallization conditions of the rocks. An emphasis is made on features that distinguish the studied Cr-spinel mineralization from typical chromitites of layered intrusions and on specific alignment of Cr-spinel grains:

1. Heterogeneous and uneven cloud-like distribution of Cr-spinel accumulations (Figures 5A and 6A).

2. Absence of planar textures and dispersed character of even the most abundant Cr-spinel disseminations (Figure 5A,C).

3. Embayments, trails and chains of Cr-spinel, which cross over the boundaries between enclosing silicates (Figure 6).

4. Ring-like alignment of Cr-spinel grains, which is not controlled by neither present grain boundaries, nor bubbles and amygdales (Figure 7).

Irregular and uneven shape of Cr-spinel-rich "clouds" and relatively homogeneous, dispersed scattering of Cr-spinel grains inside these clouds rule out the leading role of gravitational concentration of Cr-spinel in the studied assemblages. It has been suggested that a fluid-rich dynamic or even turbulent environment was responsible for local fluctuations of Cr-spinel abundance in certain parts of the "sulfide-poor" suite and prevented Cr-spinel from sinking and forming planar "reefs" [41]. From this perspective, embayments and trails of Cr-spinel could be explained by the existence of high-permeability zones inside crystallizing magma mush. Those would have acted as channeled passages for primitive impregnating melts, which precipitated abundant Cr-spinel due to a reaction with more evolved surrounding melts $[1,56]$, and in this scenario, the existence of such passages would have been reflected in textures of silicate matrix as well. However, it actually seems like $\mathrm{Cr}$-spinel textures and relationships between silicate phases weakly correlate with each other (Figure 6A-C). Instead, the observed textural oddities might be interpreted from the following perspectives:

1. Cr-spinel mineralization formed during of overprinting of already formed silicate rocks by later melts/fluids;

2. Cr-spinel grains crystallized largely before the enclosing silicates but did not experience significant displacement prior to solidification of the silicate matrix.

The first scenario favors a metamorphic or metasomatic origin for either Cr-spinel mineralization or the entire rocks themselves. Even though post-magmatic/metamorphic/metasomatic processes were ascribed to be significant contributors to the formation of PGE-Cr-spinel-rich rocks in the contact zones of the Norilsk-type intrusions $[38,41,71,84]$, there is still a strong conviction that Cr-spinel mineralization and its silicate matrix are initially magmatic in origin. Thus, it appears that crystallization of Cr-spinel and enclosing silicates occurred under specific physical conditions, in which a solid phase upon crystallization became immobile until the framework of the rock solidified (e.g., viscous magma).

Similar constraints are provided by ring-like (spherical in 3D [40]) alignment of Cr-spinel grains, which is a common feature in several of our studied rock samples (Figures 6F and 7). Such alignments have already been documented in Cr-spinel-rich rocks from different Norilsk-type intrusions [32,38,40] and assigned to foaming, which was caused by volatile exsolution from a fluidized magmatic mush [40]. Our observations show that ring-alignment of $\mathrm{Cr}$-spinel grains has no relation to former amygdales or "bubbles" that were ultimately infilled with hydrothermal minerals. Importantly, the "spheres" can be found inside unaltered silicates, where they are clearly not related to grain boundaries (Figure 7). It could be inferred that this kind of alignment was due to the agglutination of $\mathrm{Cr}$-spinel on growth fronts of the silicates, which were then overgrown. However, these aggregates are essentially sub-spherical in shape and, therefore, could be hardly considered to result from this process. Currently, no feasible mechanism(s) can be proposed to satisfactorily explain origin of these trails, chains and spherical distribution. However, these textures remained undisturbed by common "displacements" (e.g., gravitational sorting and cumulative processes) in crystallizing magmas. Therefore, we suggest that 
crystallization of $\mathrm{Cr}$-spinel and enclosing silicates took place in an environment that was viscous enough to prevent not only gravitational settling of $\mathrm{Cr}$-spinel but also relative displacement of $\mathrm{Cr}$-spinel and silicates during solidification.

\subsection{Cr-Spinel from Initial Crystallization to Low-T Modification: Chemical Controls}

Substantial compositional differences between $\mathrm{Cr}$-spinel grains enclosed in different silicates are a universal feature of intrusive rocks and are largely attributed to an extensive post-crystallization modification $[48,72-76,85]$. In the entire study, the principle features to disentangle are:

1. Different compositions of $\mathrm{Cr}$-spinel enclosed in different unaltered silicates (Figures 11A,B and 12).

2. Changing of Cr-spinel composition in altered or pseudomorph replaced silicates (Figures 8D,E, 11C-E and 12).

3. Contrasting ways of Cr-spinel evolution within different lithologies (Figure 10).

Although it would be logical to begin with the factors which control initial compositions of Cr-spinel, it is quite evident that the present ranges of Cr-spinel can hardly represent sensu stricto magmatic compositions [47], so the post-crystallization overprinting is most likely. Therefore, before considering primary features of Cr-spinel, these primary features should be constrained, and we first discuss to what extent chemical ranges of Cr-spinel under study can be attributed to overprinting processes.

\subsubsection{High-T Cr-Spinel-Silicate Equilibration}

Strong variance of Cr-spinel chemistry enclosed within different silicate minerals might result either from magma evolution (with more primitive $\mathrm{Cr}$-spinel entrapped within earlier silicates and vice versa) or from re-equilibration with the host minerals and residual melt. Textural relationships of the silicates (Figures 5D, 6B and 7E,F) imply that the first crystallizing phase was olivine, then plagioclase and finally-clinopyroxene. If only melt evolution controlled Cr-spinel chemistry, $\mathrm{Mg \#}$ would be the highest in olivine-hosted Cr-spinel grains, then gradually decrease in plagioclase-hosted, reaching minimum in those hosted in clinopyroxene. However, this scenario is not applicable for the case in this study, because $\mathrm{Cr}$-spinel enclosed in olivine have unexpectedly the lowest $\mathrm{Mg} \#$ values among $\mathrm{Cr}$-spinel from unaltered silicates (Figures 11 and 12). Thus, preference should be given to re-equilibration of $\mathrm{Cr}$-spinel with enclosing silicates.

Such mechanism for the Norilsk-type intrusions was previously explained by a model for layered intrusions [46] that applied these differences to post-cumulus re-equilibration of $\mathrm{Cr}$-spinel. Although textural evidence rules out sensu stricto cumulative origin of the studied rocks, Cr-spinel grains within plagioclase should have less equilibrated compositions because Fe-Mg exchange between plagioclase and Cr-spinel is insignificant. Meanwhile, Cr-spinel enclosed in clinopyroxene should have been strongly affected by $\mathrm{Fe}-\mathrm{Mg}$ redistribution. In addition, inclusions in plagioclase are less prone to exchange of these cations than inclusions in mafic minerals, so the initial compositions of plagioclase-hosted spinel should better survive. Pseudocolored BSE-images provide sufficient support for these considerations. In fresh rocks, Cr-spinel, settled deep within plagioclase crystals, has the highest Mg\#, while in clinopyroxene, olivine, and near the phase boundaries, the gain of Fe is notable (Figure 11A-C). In addition to this direct evidence, the studied Cr-spinel compositions presented as $\mathrm{Mg \#}$ vs $\mathrm{Cr} \#$ and $\mathrm{Fe}^{2+}$ vs $\mathrm{Fe}^{3+}$ exhibit trends that are very similar to those observed in Kilauea Iki lava lake basalts-an object, where equilibration of Cr-spinel with host silicates and evolved melt was established in real time [48]. More exactly, Cr-spinel within euhedral plagioclase can be compared with primitive $\mathrm{Cr}$-spinel inclusions from Kilauea Iki, while compositions of clinopyroxeneand olivine-hosted grains are similar to Cr-spinel which experienced modification [48] (Figure 13B). 


\subsubsection{Sub-Solidus Modification}

Along with chemical differences in Cr-spinel enclosed within different fresh silicates, there is a clear discrepancy between $\mathrm{Cr}$-spinel hosted by fresh silicates and their altered counterparts (Figures 11 and 12). In addition, Cr-spinel-2 (big coalescent grains) seems to occur predominantly within altered sites of rock, or at close proximity to them, and contain less $\mathrm{Mg}$, than $\mathrm{Cr}$-spinel-1 (small rounded isolated grains) (Figure $8 \mathrm{D}, \mathrm{E}$ ). This implies an extensive $\mathrm{Cr}$-spinel alteration driven by post-solidus processes occurring down to relatively low temperatures (stability field of fibrous amphiboles, chlorite, serpentine, albite, and sericite). Moreover, gradual transition from Cr-spinel-1 to Cr-spinel-2 (Figures 8D,E and 11E) and other morphological features of $\mathrm{Cr}$-spinel such as symplectite-like $\mathrm{Cr}$-spinel-saponite intergrowth (Figure 8G), fringes of Cr-magnetite overgrowing ferrochromite (Figure $8 \mathrm{H}$ ) and strong resorption of some Cr-spinel grains settled in chlorite and smectite matrix (Figure 8I) suggest there was a complex interplay of dissolution and re-deposition processes of $\mathrm{Cr}$-spinel during this stage.

A large amount of chemical data on Cr-spinel with regard to an enclosing silicate, make it evident that $\mathrm{Cr}$-spinel, enclosed within all altered silicates, has nearly the same main mode of $\mathrm{Mg \#}$ at ca. 15 mol. \% (Figure 11D-F). Therefore, there was a general geochemical process of modified compositions of earlier Cr-spinel. However, $\mathrm{Cr}$-spinel within the alteration products of plagioclase are to a certain extent different from their counterparts hosted by modified clinopyroxene. Firstly, Cr-spinel enclosed in former clinopyroxene has Mg\# at ca. $15 \mathrm{~mol}$. \%, while Cr-spinel hosted by sericitized and albitized plagioclase exhibits more extended range of compositions and has higher mean Mg\# values (Figure 12D,E). Second, from patterns of totally-modified sample (MR-14) it is evident that despite full replacement of plagioclase and clinopyroxene by sericite-albite-K-feldspar and amphibole-chlorite assemblages correspondingly, Cr-spinel, enclosed within former plagioclase still has pronouncedly higher Mg\# value than its counterpart, enclosed within former clinopyroxene (Figure 11F). Finally, Cr-spinel-2 appears to be more common inside altered clinopyroxene than in altered plagioclase, while jigsaw-edged $\mathrm{Cr}$-spinel grains are found exceptionally within products of plagioclase modification (Figure $8 \mathrm{~F}$ ). These facts provide a robust evidence that besides a general character of the modification processes, there were certain differences between modification of plagioclase-hosted and clinopyroxene-hosted Cr-spinel grains.

Well-described mechanisms of $\mathrm{Cr}$-spinel modification during amphibolization and chloritization of mafic minerals [77,86] suggest a gain of $\mathrm{Fe}$ and loss of $\mathrm{Mg}$ is a common. They also indicate that Cr-spinel can be replaced and overgrown by less magnesian varieties (ferritchromite down to pure magnetite). It appears that such scenario is well-applicable for the case under investigation. We propose that during post-solidus fluid-driven re-distribution of $\mathrm{Mg}$ and $\mathrm{Fe}, \mathrm{Cr}$-spinel-1 grains, enclosed within replaced clinopyroxene, gained $\mathrm{Fe}$ and experienced recrystallization to form bigger intergrown grains of Cr-spinel-2. Undoubtedly, $\mathrm{Cr}$-spinel, enclosed in plagioclase, also underwent modification during this stage, but Fe-Mg exchange was not extensive. We attribute this difference to the assumption that even altering plagioclase grains were more reluctant to $\mathrm{Mg}$ and Fe diffusion than clinopyroxene.

\subsubsection{Trivalent Cations' Systematics Pre-Determined by Parental Media}

While controls of $\mathrm{Mg}$ and $\mathrm{Fe}^{2+}$ in this particular case can be understood, the control on the behavior of trivalent cations is not easily constrained. It appears that the systematics of trivalent cations in Cr-spinel does not depend on post-solidus alteration: $\mathrm{Cr}$-spinel in both altered and unaltered silicates display a full range of trivalent cations' contents (Figure 13).

It follows that the main factor, governing systematics of $\mathrm{Fe}^{3+}, \mathrm{Cr}$, and $\mathrm{Ti}$, is the $\mathrm{Cr}$-spinel-bearing lithology (Figure 10). This feature is well demonstrated by the samples from the Medvezhy Ruchey mine and, to a lesser extent, manifested in the samples from the MS-24 core. Moreover, Cr-spinel from different lithologies, neighboring each other within the same thin section, exhibit considerable difference in the behavior of these elements. Titanium, $\mathrm{Fe}^{3+}$, and, to a lesser extent, $\mathrm{Cr}$ abundances in $\mathrm{Cr}$-spinel from different lithologies are different for even the most magnesian $\mathrm{Cr}$-spinel grains and these differences become more significant, ultimately resulting in divergent trends 
(Figure 10). Comparing those chemical features with a kind of the host lithology, we assume that the "normal" chromite-ferritchromite-Cr-magnetite pattern is characteristic of more melanocratic, gabbro-like lithologies, while the chromite-ferritchromite-ulvőspinel pattern seems to dominate in leucogabbro/troctolitic lithologies. This is perhaps well-illustrated by the sample MS24-323.4, where leucogabbro and olivine-rich gabbro are in contact within a studied thin section, and Cr-spinel compositions show some kind of divergence on $\mathrm{Mg} \#-\mathrm{Cr}_{2} \mathrm{O}_{3}, \mathrm{Fe}^{2+}-\mathrm{Fe}^{3+}$, and $\mathrm{Fe}^{3+}$-Ti diagrams (Figure 10).

Therefore, the differences in trivalent cation systematics appear to originate from conditions of initial crystallization, which were therefore contrasting for the leucogabbro/troctolite and olivine-gabbro lithological domains. Assuming that the initial crystallization took place from different viscous magmas (see Section 5.2), we deem that magma composition largely pre-determined the trivalent cations' systematics, while the overprinting processes significantly extended ranges of their contents, resulting in the divergent trends. However, attention should be paid to striking differences in $\mathrm{Fe}^{3+} / \mathrm{Fe}^{2+}$ systematics in Cr-spinel from different lithologies (Figure 10C,D). Likely, these differences originated not only from different magma compositions but also from different redox conditions. Therefore, we can suppose that leucogabbro/troctolite lithological domains were initially crystallized in unusually reduced conditions, while olivine gabbro lithological domains were in relatively oxidized circumstances, resembling those for the lower zones of the Norilsk-type intrusions (Figure 9F).

\section{Conclusions}

The investigation of Cr-spinel, which was performed on a set of samples of PGM-Cr-spinel-rich rocks ("sulfide-poor" PGE ores) from the upper zone of the Norilsk-1 intrusion, places several genetic constrains on the $\mathrm{Cr}$-spinel and on rocks themselves. Initial crystallization of the rocks took place in a heterogeneous environment, where $\mathrm{Cr}$-spinel-rich lithologies (leucogabbro/troctolites and olivine-rich ophitic gabbros) crystallized in situ from viscous batches of magmas with different composition and redox state. Expansion of Cr-spinel compositional ranges was further promoted by different extents of its re-equilibration with enclosing silicates and residual melt and, importantly, by post-solidus modification and re-crystallization, which is thought to have lasted down to low temperatures (stability field of chlorite, smectite and sericite). General trends with $\mathrm{Ti}$ and Fe contents increasing and $\mathrm{Mg}$ and Al contents decreasing are in accordance with trends, established for other differentiated intrusions. However, the revealed ranges of $\mathrm{Cr}$-spinel compositions are unique and are not observed in any other intrusions. The study gives an example of how significantly composition of Cr-spinel may change due to various post-crystallization processes and provides further evidence of substantial Cr mobility and Cr-spinel recrystallization during post-magmatic overprinting.

Supplementary Materials: The following are available online at http://www.mdpi.com/2075-163X/10/6/498/s1, Table S1. Chemical composition of Cr-spinel grains from the studied samples with regard to enclosing silicates and affinity to PGM-sulfide assemblages.

Author Contributions: I.F.C., L.M.Z., and A.E.I. elaborated the subject and main idea of the paper, L.M.Z., A.Y.S., and M.P.G. performed sampling, I.F.C., L.M.Z., A.Y.S., N.D.T., A.A., and V.M.C. performed sample preparation and acquired analytical data, I.F.C. processed the acquired data, I.F.C. and T.N.A. prepared the illustrations, I.F.C., A.A., A.E.I., and T.N.A. produced final manuscript, V.S.K. provided supervision of the research, administrated the project and acquired funding. All authors have read and agreed to the published version of the manuscript.

Funding: The study was conducted under the State Assignment to the V.S. Sobolev Institute of Geology and Mineralogy SB RAS and was supported by the Russian Science Foundation grant 19-17-13013. Sampling and analytics were partly supported by the Russian Foundation for Basic Research grant 16-05-00945a.

Acknowledgments: The authors appreciate a great effort of four anonymous reviewers, which recommendations strongly improved the study. We also thank many people who assisted this study: Maya Kamenetsky and Nadezhda Belkina (sample preparation); Elena Nigmatullina, Victoria Danilovskaya, Nikolay Karmanov, Mikhail Khlestov, and Karsten Goemann (EPMA assistance); and Andrey Lavrenchuk and Anastasiya Iskrina (who helped to optimize data processing in MS Excel and Adobe Photoshop respectively). We are particularly grateful to Norilskgeologiya LTD, which assisted in field work and core sampling. We thank Steve Barnes, Sergey Sluzhenikin, Viktor Ryabov, Valery Kalugin, Marina Yudovskaya, and Anton Kutyrev for informal discussion, which helped to make implications. 
Conflicts of Interest: The authors have no conflicts or other issues to declare.

\section{References}

1. Campbell, I.H.; Murck, B.W. Petrology of the G and H Chromitite Zones in the Mountain View Area of the Stillwater Complex, Montana. J. Petrol. 1993, 34, 291-316. [CrossRef]

2. Eales, H.; Cawthorn, R. The bushveld complex. In Developments in Petrology; Elsevier: Amsterdam, The Netherlands, 1996; Volume 15, pp. 181-229.

3. McCallum, I.S. The Stillwater Complex. In Developments in Petrology; Cawthorn, R.G., Ed.; Elsevier: Amsterdam, The Netherlands, 1996; Volume 15, pp. 441-483.

4. Mungall, J.E.; Naldrett, A.J. Ore deposits of the platinum-group elements. Elements 2008, 4, $253-258$. [CrossRef]

5. Wager, R. The mechanism of adcumulus growth in the layered series of the Skaergaard intrusion. Mineral. Soc. Am. Spec. Pap. 1963, 1, 1-9.

6. Duzhikov, O.; Distler, V.; Rylkova, G.; Naldrett, A. Geology and Metallogeny of Sulfide Deposits Noril'sk Region USSR; PUBCO: Cleveland, OH, USA, 1992.

7. Krivolutskaya, N.; Tolstykh, N.; Kedrovskaya, T.; Naumov, K.; Kubrakova, I.; Tyutyunnik, O.; Gongalsky, B.; Kovalchuk, E.; Magazina, L.; Bychkova, Y.; et al. World-Class PGE-Cu-Ni Talnakh Deposit: New Data on the Structure and Unique Mineralization of the South-Western Branch. Minerals 2018, 8, 124. [CrossRef]

8. Naldrett, A.J. Magmatic Sulfide Deposits: Geology, Geochemistry and Exploration; Springer Science \& Business Media: Berlin/Heidelberg, Germany, 2013.

9. Sluzhenikin, S.F. Platinum-Copper-Nickel and Platinum Ores of Norilsk Region and Their Ore Mineralization. Russ. J. Gen. Chem. 2011, 81, 1288-1301. [CrossRef]

10. Tolstykh, N.; Krivolutskaya, N.; Safonova, M.; Shapovalova, I.Y.; Zhitova, L.; Abersteiner, A. Unique Cu-rich sulphide ores of the Southern-2 orebody in the Talnakh Intrusion, Noril'sk area (Russia): Geochemistry, mineralogy and conditions of crystallization. Ore Geol. Rev. 2020, 122, 103525. [CrossRef]

11. Sluzhenikin, S.F.; Distler, V.V.; Grigoryeva, A.B. Sulfide-poor platinum ores of the Noril'sk region-Perspective sources of noble metals. Arctika Ekol. Ekon. 2016, 24, 32-45.

12. Ryabov, V.V.; Tsymbalist, V.G.; Yakobi, I.Y. Concentration of chromium and platinum-group elements in the roofs of Noril'sk-type layered intrusions. Dokl. Akad. Nauk Sssr 1982, 226, 466-469.

13. Sluzhenikin, S.; Distler, V.; Dyuzhikov, O.; Kravtsov, V.; Kunilov, V.; Laputina, I.; Turovtsev, D. Low sulfide platinum mineralization in the Noril'sk differentiated intrusive bodies. Geol. Rudn. Mestorozhdenii 1994, 36, 195-217. (In Russian)

14. Smirnov, M.F. The Structure of Norilsk Nickel-Bearing Intrusions and Sulfide Ores; Nedra: Moscow, Russia, 1966. (In Russian)

15. Alapieti, T.T.; Kujanpaa, J.; Lahtinen, J.J.; Papunen, H. The Kemi stratiform chromitite deposit, northern Finland. Econ. Geol. 1989, 84, 1057-1077. [CrossRef]

16. Eales, H. Caveats in defining the magmas parental to the mafic rocks of the Bushveld Complex, and the manner of their emplacement: Review and commentary. Mineral. Mag. 2002, 66, 815-832. [CrossRef]

17. Sharkov, E.; Chistyakov, A. The Early Paleoproterozoic Monchegorsk layered mafite-ultramafite massif in the Kola Peninsula: Geology, petrology, and ore potential. Petrology 2012, 20, 607-639. [CrossRef]

18. Cameron, E.N. The Lower Zone of the Eastern Bushveld Complex in the Olifants River Trough. J. Petrol. 1978, 19, 437-462. [CrossRef]

19. Hulbert, L.; Von Gruenewaldt, G. Textural and compositional features of chromite in the lower and critical zones of the Bushveld Complex south of Potgietersrus. Econ. Geol. 1985, 80, 872-895. [CrossRef]

20. Latypov, R.; Chistyakova, S.; Barnes, S.J.; Hunt, E.J. Origin of platinum deposits in layered intrusions by in situ crystallization: Evidence from undercutting Merensky Reef of the Bushveld Complex. J. Petrol. 2017, 58, 715-761. [CrossRef]

21. Lipin, B.R. Pressure increases, the formation of chromite seams, and the development of the ultramafic series in the Stillwater Complex, Montana. J. Petrol. 1993, 34, 955-976. [CrossRef]

22. Maier, W.D.; Barnes, S.-J.; Groves, D. The Bushveld Complex, South Africa: Formation of platinum-palladium, chrome-and vanadium-rich layers via hydrodynamic sorting of a mobilized cumulate slurry in a large, relatively slowly cooling, subsiding magma chamber. Miner. Depos. 2013, 48, 1-56. [CrossRef] 
23. Vukmanovic, Z.; Barnes, S.J.; Reddy, S.M.; Godel, B.; Fiorentini, M.L. Morphology and microstructure of chromite crystals in chromitites from the Merensky Reef (Bushveld Complex, South Africa). Contrib. Mineral. Petrol. 2013, 165, 1031-1050. [CrossRef]

24. Waters, C.; Boudreau, A. A reevaluation of crystal-size distributions in chromite cumulates. Am. Mineral. 1996, 81, 1452-1459. [CrossRef]

25. Yudovskaya, M.A.; Kinnaird, J.A. Chromite in the Platreef (Bushveld Complex, South Africa): Occurrence and evolution of its chemical composition. Miner. Depos. 2010, 45, 369-391. [CrossRef]

26. Henderson, P.; Suddaby, P. The nature and origin of the chrome-spinel of the Rhum layered intrusion. Contrib. Mineral. Petrol. 1971, 33, 21-31. [CrossRef]

27. Spandler, C.; Mavrogenes, J.; Arculus, R. Origin of chromitites in layered intrusions: Evidence from chromite-hosted melt inclusions from the Stillwater Complex. Geology 2005, 33, 893-896. [CrossRef]

28. Tolstykh, N.D.; Zhitova, L.M.; Shapovalova, M.O.; Chayka, I.F. The evolution of the ore-forming system in the low sulfide horizon of the Noril'sk 1 intrusion, Russia. Mineral. Mag. 2019, 83, 673-694. [CrossRef]

29. Geoinformmark. Geological Map of Norilsk Ore Region at a Scale of 1:200,000 (explanatory Note); Strunin, B.M., Ed.; Geoinformmark: Moscow, Russia, 1991. (In Russian)

30. Ivanov, M.K.; Ivanova, T.K.; Tarasov, A.V.; Shatkov, V.A. Characteristics of petrology and ore mineralization of differentiated intrusions of the Noril'sk ore junction (Noril'sk I, Noril'sk II and Mt. Chomaya deposits). In Petrology and Mineralization of the Talnakh and Noril'sk Differentiated Intrusions; Nedra: Leningrad, Russia, 1971; pp. 197-305. (In Russian)

31. Likhachev, A. Ore-bearing intrusions of the Noril'sk region. In Proceedings of Sudbury-Noril'sk Symp; Ontario Geological Survey: Sudbury, ON, Canada, 1994; pp. 185-202.

32. Ryabov, V.; Gora, M.; Shevko, A.Y. Trap Magmatism and Ore Formation in the Siberian Noril'sk Region; Springer: Berlin/Heidelberg, Germany, 2014.

33. Distler, V.; Kunilov, V. Geology and ore deposits of the Noril'sk Region. In Proceedings of the Seventh International Platinum Symposium; Moskovsky Contact Press: Moscow, Russia, 1994.

34. Krivolutskaya, N. Evolution of Trap Magmatism and Processes Producing Pt-Cu-Ni Mineralization in the Noril'sk Area; KMK: Moscow, Russia, 2014. (In Russian)

35. Sluzhenikin, S.; Krivolutskaya, N.; Rad'Ko, V.; Malitch, K.; Distler, V.; Fedorenko, V. Ultramafic-Mafic Intrusions, Volcanic Rocks and PGE-Cu-Ni Sulfide Deposits of the Noril'sk Province, Polar Siberia. Field Trip Guidebook; Institute of Geology of Ore Deposits, Petrography, Mineralogy and Geochemistry, Yekaterinburg, Russia: Moscow, Russia, 2014.

36. Turovtsev, D. Contact Metamorphism of the Noril'sk Intrusions; Scientific World: Moscow, Russia, 2002. (In Russian)

37. Zen'ko, T.; Czamanske, G. Spatial and petrologic aspects of the intrusions of the Noril'sk and Talnakh ore junctions. In Proceedings of The Sudbury-Norilsk Symposium; Ontario Geological Survey Special Publication: Sudbury, ON, Canada, 1994; pp. 263-282.

38. Sluzhenikin, S.F. Sulfide-Low Platinum Mineralization in Differentiated Basite-Hyperbasite Intrusions of the Noril'sk Region; Institute of Geology of Ore Deposits, Petrography, Mineralogy, and Geochemistry, Russian Academy of Sciences: Moscow, Russia, 2000. (In Russian)

39. Lavrent'ev, Y.G.; Karmanov, N.; Usova, L. Electron probe microanalysis of minerals: Microanalyzer or scanning electron microscope? Russ. Geol. Geophys. 2015, 56, 1154-1161. [CrossRef]

40. Schoneveld, L.E.; Barnes, S.J.; Kamenetsky, V.S.; Le Vaillant, M.; Godel, B.; Sluzhenikin, S.F.; Yudovskaya, M.A. Oxide-sulfide-magma-bubble interactions in spinel-rich taxites from the Norilsk-Talnakh intrusions, Siberia. Econ. Geol. 2020, in press.

41. Chayka, I.F.; Kamenetsky, V.S.; Zhitova, L.M.; Izokh, A.E.; Tolstykh, N.D.; Abersteiner, A.; Lobastov, B.M.; Yakich, T.Y. Hybrid nature of the PGE-chromite-rich rocks of the Norilsk-1 intrusion: Genetic constraints from Cr-spinel and spinel-hosted multiphase inclusions. Econ. Geol. 2020, in press.

42. Barnes, S.J.; Roeder, P.L. The range of spinel compositions in terrestrial mafic and ultramafic rocks. J. Petrol. 2001, 42, 2279-2302. [CrossRef]

43. Krivolutskaya, N.A.; Sobolev, A.I. Siberian Traps and Pt.-Cu-Ni Deposits in the Noril'sk Area; Springer: Berlin/Heidelberg, Germany, 2016. 
44. Ryabov, V.; Bakumenko, I.; Fominykh, I. Dendritic megacrystals of clinopyroxene in trap rocks of the Norilsk region and some questions concerning their formation. Akade Nauk SSSR Sib. Otd. Inst. Geol. Geofiz. Trudy 1977, 349, 47-74. (In Russian)

45. Zolotukhin, V.; Almukhamedov, A. Basalts of the Siberian Platform: Conditions of occurrences, composition and mechanism of formation. In Traps of Siberia and Deccan, Similarities and Differences; Nauka: Novosibirsk, Russia, 1991; pp. 7-38. (in Russian)

46. Barnes, S.J.; Kunilov, V. Spinels and Mg ilmenites from the Noril'sk 1 and Talnakh intrusions and other mafic rocks of the Siberian flood basalt province. Econ. Geol. 2000, 95, 1701-1717. [CrossRef]

47. Kamenetsky, V.S.; Crawford, A.J.; Meffre, S. Factors controlling chemistry of magmatic spinel: An empirical study of associated olivine, Cr-spinel and melt inclusions from primitive rocks. J. Petrol. 2001, 42, 655-671. [CrossRef]

48. Scowen, P.; Roeder, P.; Helz, R. Reequilibration of chromite within Kilauea Iki lava lake, Hawaii. Contrib. Mineral. Petrol. 1991, 107, 8-20. [CrossRef]

49. Brown, G.M. The layered ultrabasic rocks of Rhum, Inner Hebrides. Philos. Trans. R. Soc. London Ser. B Biol. Sci. 1956, 240, 1-54.

50. Emeleus, C.H. The Rhum Layered Complex, Inner Hebrides, Scotland. In Origins of Igneous Layering; Parsons, I., Ed.; Springer: Dordrecht, The Netherlands, 1987; pp. 263-286. [CrossRef]

51. Maier, W.; Barnes, S.-J. Platinum-group elements in the UG1 and UG2 chromitites, and the Bastard reef, at Impala platinum mine, western Bushveld Complex, South Africa: Evidence for late magmatic cumulate instability and reef constitution. South Afr. J. Geol. 2008, 111, 159-176. [CrossRef]

52. McDonald, J.A. Liquid immiscibility as one factor in chromitite seam formation in the Bushveld Igneous Complex. Econ. Geol. 1965, 60, 1674-1685. [CrossRef]

53. Okrugin, A.V. Crystallization-immiscibility model of PGE-chromitite ores origin in mafic-ultramafic complexes. Tikhookeanskaya Geol. 2004, 23, 63-75. (In Russian)

54. Cawthorn, R. Pressure fluctuations and the formation of the PGE-rich Merensky and chromitite reefs, Bushveld Complex. Mineral. Depos. 2005, 40, 231-235. [CrossRef]

55. Latypov, R.; Costin, G.; Chistyakova, S.; Hunt, E.J.; Mukherjee, R.; Naldrett, T. Platinum-bearing chromite layers are caused by pressure reduction during magma ascent. Nat. Commun. 2018, 9, 1-7. [CrossRef]

56. Irvine, T. Origin of chromitite layers in the Muskox intrusion and other stratiform intrusions: A new interpretation. Geology 1977, 5, 273-277. [CrossRef]

57. Kinnaird, J.; Kruger, F.; Nex, P.; Cawthorn, R. Chromitite formation-A key to understanding processes of platinum enrichment. Appl. Earth Sci. 2002, 111, 23-35. [CrossRef]

58. Talkington, R.; Watkinson, D.; Whittaker, P.; Jones, P. Platinum-group minerals and other solid inclusions in chromite of ophiolitic complexes: Occurrence and petrological significance. Tschermaks Mineral. Petrogr. Mitt. 1984, 32, 285-301. [CrossRef]

59. Whittaker, P.J.; Watkinson, D.H. Genesis of chromitite from the Mitchell Range, central British Columbia. Can. Mineral. 1984, 22, 161-172.

60. Johan, Z. Origin of chromite deposits in ophiolitic complexes: Evidence for a volatile-and sodium-rich reducing fluid phase. Forschr. Mineral. 1983, 61, 105-107.

61. Johan, Z. Chromite Deposits in the Massif du Sud Ophiolite, New Caledonia: Genetic Considerations, Chromites, UNESCO's IGCP-197 Project on Metallogeny of Ophiolites; Theophrastus Publications: Athens, Greece, 1986.

62. Arai, S.; Abe, N. Reaction of orthopyroxene in peridotite xenoliths with alkali-basalt melt and its implication for genesis of alpine-type chromitite. Am. Mineral. 1995, 80, 1041-1047. [CrossRef]

63. Irvine, T. Infiltration metasomatism, adcumulus growth, and double diffusive fractional crystallization in the Muskox intrusion and other layered intrusions. In Physics of Magmatic Processes; Princeton University Press: Princeton, NJ, USA, 1980; pp. 325-383.

64. Mathez, E.A.; Kinzler, R.J. Metasomatic chromitite seams in the Bushveld and Rum Layered intrusions. Elements 2017, 13, 397-402. [CrossRef]

65. Nikolaev, G.; Ariskin, A.; Barmina, G. Numerical Modeling of the Effects of Major Elements on the Solubility of Chrome-Spinel and a Likely Solution of the Problem of the Origin of Chromitite. Dolkady Earth Sci. 2019, 487, 791-794. [CrossRef] 
66. Kutyrev, A.; Kamenetsky, V.; Sidorov, E.; Abersteiner, A.; Chubarov, V. Silicate inclusions in isoferroplatinum: Constraints on the origin of platinum mineralization in podiform chromitites. Ore Geol. Rev. 2020, 119, 103367. [CrossRef]

67. Mochalov, A. A genetic model of PGM hosted in cumulative gabbro-pyroxenite-dunite complexes of the Koryak Highland, Russia. Geol. Ore Depos. 2013, 55, 145-161. [CrossRef]

68. Pushkarev, E.; Kamenetsky, V.; Morozova, A.; Khiller, V.; Glavatskykh, S.; Rodemann, T. Ontogeny of ore Cr-spinel and composition of inclusions as indicators of the pneumatolytic-hydrothermal origin of PGM-bearing chromitites from Kondyor massif, the Aldan Shield. Geol. Ore Depos. 2015, 57, 352-380. [CrossRef]

69. Akizawa, N.; Arai, S. Petrology of mantle diopsidite from W adi F izh, northern O man ophiolite: Cr and REE mobility by hydrothermal solution. Island Arc 2014, 23, 312-323. [CrossRef]

70. Arai, S.; Akizawa, N. Precipitation and dissolution of chromite by hydrothermal solutions in the Oman ophiolite: New behavior of $\mathrm{Cr}$ and chromite. Am. Mineral. 2014, 99, 28-34. [CrossRef]

71. Ryabov, V.V.; Shevko, A.Y.; Simonov, O.N.; Anoshin, G.N. Composition of the platinum-bearing chromium-rich skarns of Talnakh (Noril'sk region). Russ. Geol. Geophys. 1996, 37, 60-75. (In Russian)

72. Evans, B.W.; Wright, T.L. Composition of liquidus chromite from the 1959 (Kilauea Iki) and 1965 (Makaopuhi) eruptions of Kilauea volcano, Hawaii. Am. Mineral. J. Earth Planet. Mater. 1972, 57, 217-230.

73. Barnes, S.J.; Zhong-Li, T. Chrome spinels from the Jinchuan Ni-Cu sulfide deposit, Gansu Province, People's Republic of China. Econ. Geol. 1999, 94, 343-356. [CrossRef]

74. Irvine, T. Terminology for layered intrusions. J. Petrol. 1982, 23, 127-162. [CrossRef]

75. Dick, H.J.B.; Bullen, T. Chromian spinel as a petrogenetic indicator in abyssal and alpine-type peridotites and spatially associated lavas. Contrib. Mineral. Petrol. 1984, 86, 54-76. [CrossRef]

76. Irvine, T. Chromian spinel as a petrogenetic indicator: Part 2. Petrologic applications. Can. J. Earth Sci. 1967, 4, 71-103. [CrossRef]

77. Abzalov, M.Z. Chrome-spinels in gabbro-wehrlite intrusions of the Pechenga area, Kola Peninsula, Russia: Emphasis on alteration features. Lithos 1998, 43, 109-134. [CrossRef]

78. Burkhard, D.J. Accessory chromium spinels: Their coexistence and alteration in serpentinites. Geochim. Cosmochim. Acta 1993, 57, 1297-1306. [CrossRef]

79. Colás, V.; González-Jiménez, J.M.; Griffin, W.L.; Fanlo, I.; Gervilla, F.; O’Reilly, S.Y.; Pearson, N.J.; Kerestedjian, T.; Proenza, J.A. Fingerprints of metamorphism in chromite: New insights from minor and trace elements. Chem. Geol. 2014, 389, 137-152. [CrossRef]

80. Merlini, A.; Grieco, G.; Diella, V. Ferritchromite and chromian-chlorite formation in mélange-hosted Kalkan chromitite (Southern Urals, Russia). Am. Mineral. 2009, 94, 1459-1467. [CrossRef]

81. Huang, J.; Hao, J.; Huang, F.; Sverjensky, D. Mobility of chromium in high temperature crustal and upper mantle fluids. Geochem. Perspect. Lett. 2019, 12,1-6. [CrossRef]

82. Watenphul, A.; Schmidt, C.; Jahn, S. Cr (III) solubility in aqueous fluids at high pressures and temperatures. Geochim. Cosmochim. Acta. 2014, 126, 212-227. [CrossRef]

83. Likhachev, A. Role of leucocratic gabbro in the generation of Noril'sk differentiated intrusions. Izv. Akad. Nauk SSSR Geol. Ser. 1965, 10, 75-89. (In Russian)

84. Shevko, A.Y.; Kalugin, V.; Gora, M.; Karmanov, N. The First Find of Oxyborates in Rocks of the Norilsk-1 Intrusion (Northwestern Siberian Platform). Dokl. Earth Sci. 2019, 488, 1100-1102. [CrossRef]

85. Cameron, E.N. Postcumulus and subsolidus equilibration of chromite and coexisting silicates in the Eastern Bushveld Complex. In Chromium: Its Physicochemical Behavior and Petrologic Significance; Elsevier: Amsterdam, The Netherlands, 1976; pp. 1021-1033.

86. Grieco, G.; Merlini, A. Chromite alteration processes within Vourinos ophiolite. Int. J. Earth Sci. 2012, 101, 1523-1533. [CrossRef]

(C) 2020 by the authors. Licensee MDPI, Basel, Switzerland. This article is an open access article distributed under the terms and conditions of the Creative Commons Attribution (CC BY) license (http://creativecommons.org/licenses/by/4.0/). 